University of Nebraska - Lincoln

DigitalCommons@University of Nebraska - Lincoln

\title{
A macroinvertebrate assessment of Ozark streams located in lead-zinc mining areas of the Viburnum Trend in southeastern Missouri, USA
}

\author{
Barry Poulton \\ U.S. Geological Survey, bpoulton@usgs.gov \\ Ann L. Allert \\ U.S. Geological Survey, aallert@usgs.gov \\ John M. Besser \\ U.S. Geological Survey, jbesser@usgs.gov \\ Christopher J. Schmitt \\ U.S. Geological Survey, cjschmitt@usgs.gov \\ William G. Brumbaugh \\ U.S. Geological Survey, bbrumbaugh@usgs.gov \\ See next page for additional authors
}

Follow this and additional works at: https://digitalcommons.unl.edu/usgsstaffpub

Poulton, Barry; Allert, Ann L.; Besser, John M.; Schmitt, Christopher J.; Brumbaugh, William G.; and Fairchild, James F., "A macroinvertebrate assessment of Ozark streams located in lead-zinc mining areas of the Viburnum Trend in southeastern Missouri, USA" (2010). USGS Staff -- Published Research. 561. https://digitalcommons.unl.edu/usgsstaffpub/561

This Article is brought to you for free and open access by the US Geological Survey at DigitalCommons@University of Nebraska - Lincoln. It has been accepted for inclusion in USGS Staff -- Published Research by an authorized administrator of DigitalCommons@University of Nebraska - Lincoln. 


\section{Authors}

Barry Poulton, Ann L. Allert, John M. Besser, Christopher J. Schmitt, William G. Brumbaugh, and James F. Fairchild 


\title{
A macroinvertebrate assessment of Ozark streams located in lead-zinc mining areas of the Viburnum Trend in southeastern Missouri, USA
}

\author{
Barry C. Poulton • Ann L. Allert • \\ John M. Besser • Christopher J. Schmitt • \\ William G. Brumbaugh • James F. Fairchild
}

Received: 28 October 2008 / Accepted: 10 March 2009 / Published online: 4 April 2009

(C) US Government 2009

\begin{abstract}
The Viburnum Trend lead-zinc mining subdistrict is located in the southeast Missouri portion of the Ozark Plateau. In 2003 and 2004, we assessed the ecological effects of mining in several watersheds in the region. We included macroinvertebrate surveys, habitat assessments, and analysis of metals in sediment, pore water, and aquatic biota. Macroinvertebrates were sampled at 21 sites to determine aquatic life impairment status (full, partial, or nonsupport) and relative biotic condition scores. Macroinvertebrate biotic condition scores were significantly correlated with cadmium, nickel, lead, zinc, and specific conductance in 2003 ( $r=-0.61$ to -0.68$)$ and with cadmium, lead, and pore water toxic units in 2004 ( $r=-0.55$ to -0.57$)$. Reference sites were fully supporting of aquatic life and had the lowest metals concentrations and among the highest biotic condition scores in both years. Sites directly downstream from mining and related activities were partially supporting, with biotic condition scores $10 \%$ to $58 \%$ lower than reference sites. Sites located greater distances downstream from mining activities had intermediate scores and
\end{abstract}

B. C. Poulton ( $\varangle)$ · A. L. Allert · J. M. Besser ·

C. J. Schmitt - W. G. Brumbaugh · J. F. Fairchild

Columbia Environmental Research Center,

U.S. Geological Survey, 4200 New Haven Rd.,

Columbia, MO 65201, USA

e-mail: bpoulton@usgs.gov concentrations of metals. Results indicate that elevated concentrations of metals originating from mining activities were the underlying cause of aquatic life impairment in several of the streams studied. There was general concurrence among the adversely affected sites in how the various indicators responded to mining activities during the overall study.

Keywords Bioassessment - Macroinvertebrates • Streams $\cdot$ Mining $\cdot$ Ozark region

\section{Introduction}

The mining of metal ores and subsequent transport and erosion of mine wastes into waterways has been identified as one of the leading causes of stream impairment in the central USA (USEPA 2000). Most publications related to the effects of mining on invertebrates and fish in stream and river systems have been from the Rocky Mountain and Appalachian regions. In those areas, adverse effects have been attributed to low $\mathrm{pH}$ and the associated increase in the bioavailability of heavy metals. In the western USA, most hard rock mining has primarily been for extraction of molybdenum $(\mathrm{Mo})$, copper $(\mathrm{Cu})$, cobalt $(\mathrm{Co})$, and precious metals such as gold ( $\mathrm{Au}$ ) and silver (Ag), whereas the eastern USA has been primarily mined for 
coal (Ferderer 1996). In the Interior Highlands of the central USA, including the Missouri portion of the Ozark Plateau physiographic province (i.e., the Ozark region), lead $(\mathrm{Pb})$ and zinc $(\mathrm{Zn})$ have been extensively mined within the last century. Streams and rivers draining the karst geology of this region are well-buffered with dolomitic limestone substrates (Haggard et al. 2001; Petersen et al. 1998). The Viburnum Trend Subdistrict (a portion of the southeast Missouri Mining District) remains a primary producer of $\mathrm{Pb}$ and $\mathrm{a}$ secondary producer of $\mathrm{Zn}, \mathrm{Cu}$, and $\mathrm{Ag}$ (Missouri Department of Natural Resources (MDNR) 2004; Mining and Quarry World 2004). Environmental $\mathrm{Pb}$ contamination has been a primary concern because of the problems associated with exposure and uptake by fish, wildlife, and invertebrates (reviewed by Eisler 1988).

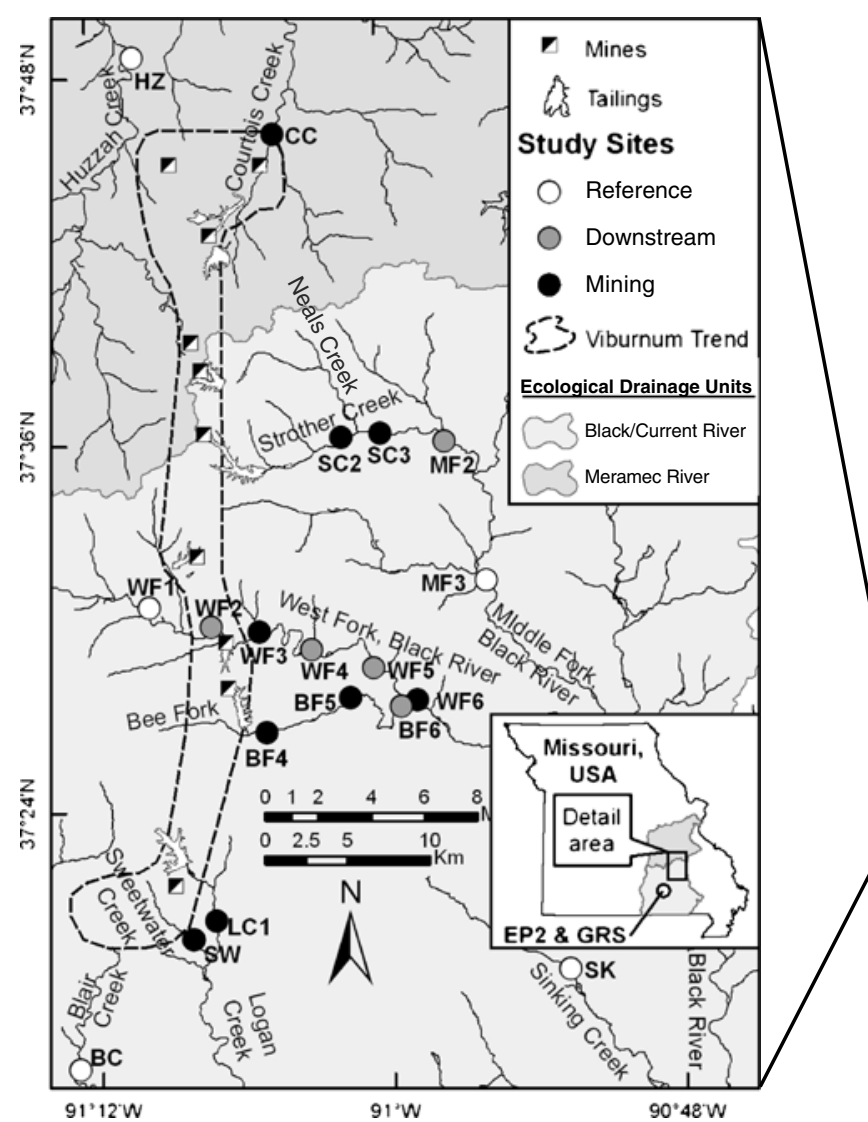

Fig. 1 Location of mining activity in the Viburnum Trend of southeastern Missouri, the 21 macroinvertebrate study sites that were sampled in September 2003 and 2004 in
Adverse effects of metals that are commonly associated with mining activities, specifically on invertebrates, were reported as early as the 1960 s (Reish and Gerlinger 1964), but most of the publications cited by Eisler (1988) were from studies conducted after 1970. In the late 1960s, mining activity in Missouri shifted from the Old Lead Belt to the Viburnum Trend (Fig. 1, inset), and adverse effects of heavy metal pollution in area streams were reported shortly thereafter (Gale et al. 1973; Ryck 1974; Duchrow et al. 1980; Duchrow 1983). With time, mining activity in the Viburnum Trend shifted from north to south as ore deposits were depleted and new mines opened. Currently, the Viburnum Trend remains a primary producer of $\mathrm{Pb}$ and a secondary producer of $\mathrm{Zn}$ and $\mathrm{Cu}$ (Jessey 1981). Most deep shaft-type mines in the Viburnum Trend have been developed on lands

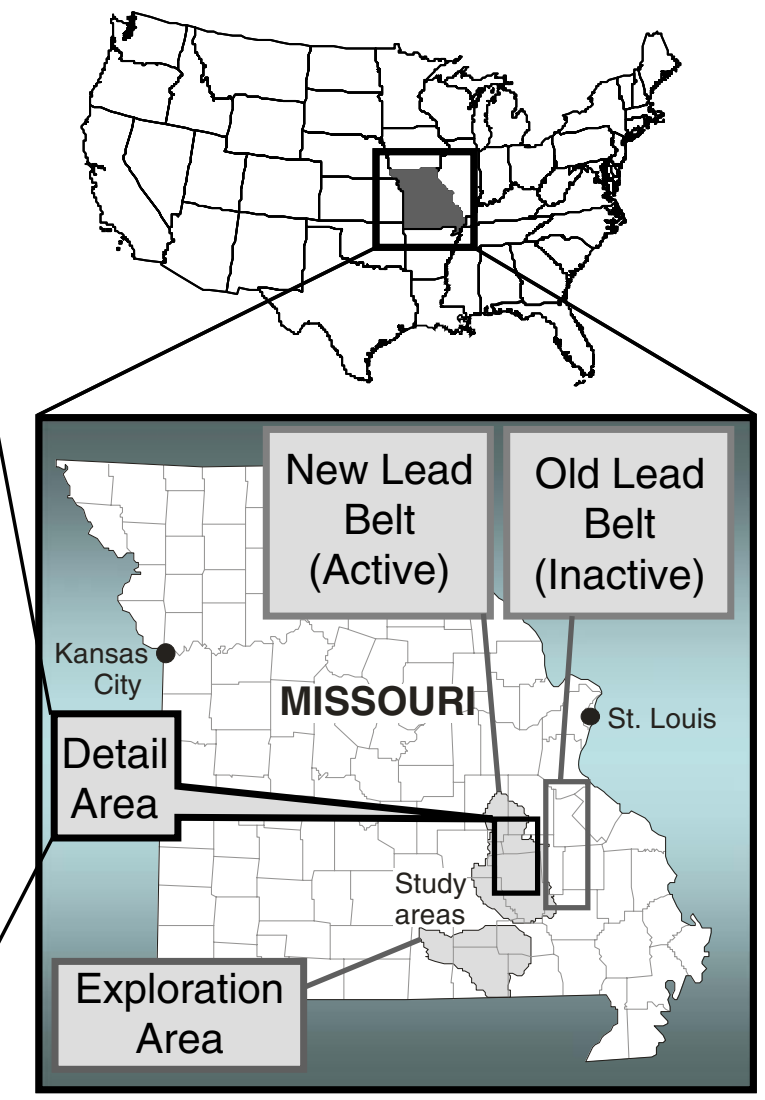

the Meramec River and Black/Current River Ecological Drainage Units (EDU), and the Exploration Area (EA). Site identifications are defined in Table 1 


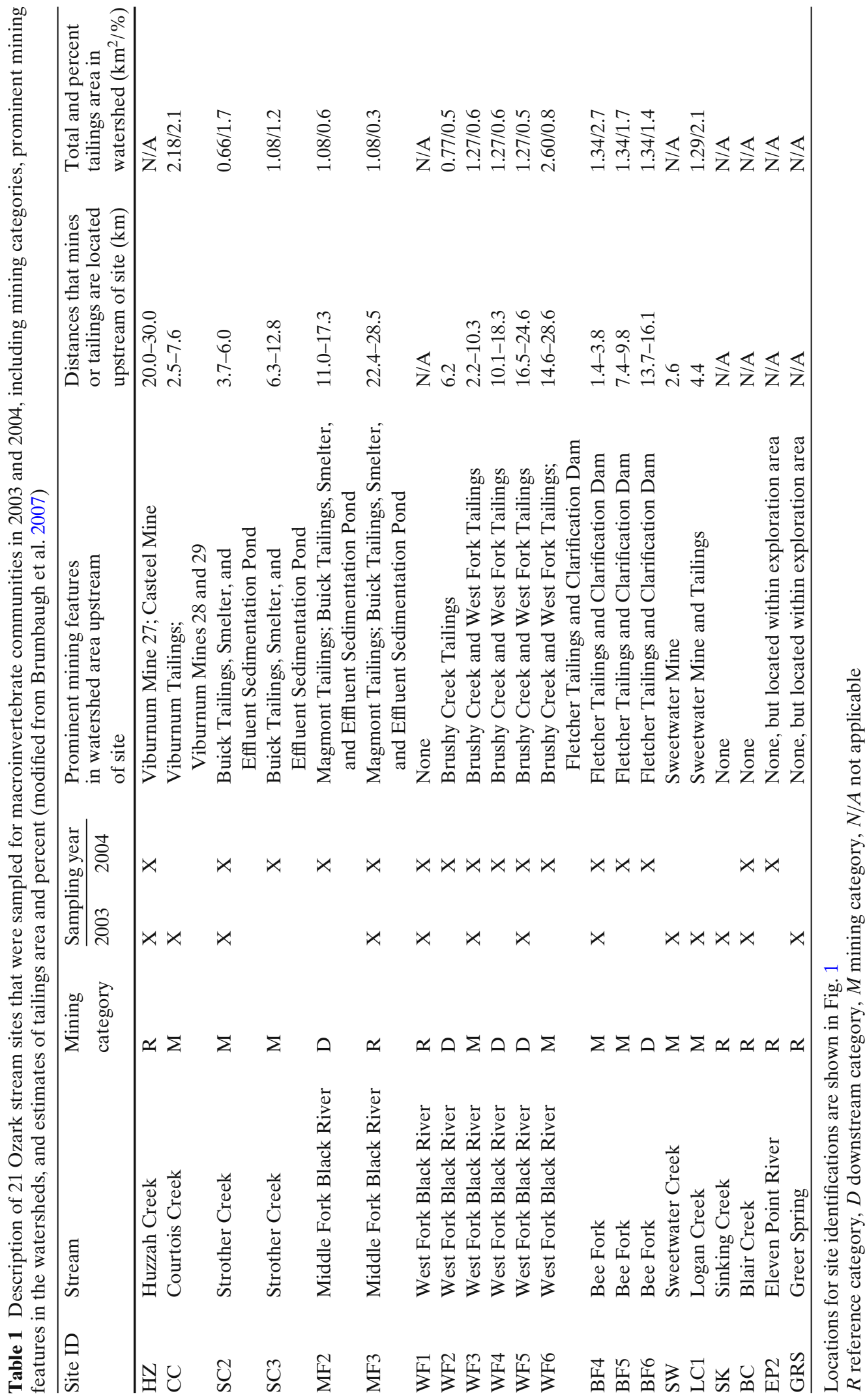


that are adjacent to, or formerly within, the Mark Twain National Forest (U.S. Department of Agriculture 2005). Beginning in the late 1970s to the present, periodic exploratory drilling to locate new $\mathrm{Pb}$ deposits has been conducted. The exploration area (EA) is located about $30 \mathrm{~km}$ south of the Viburnum Trend (Kleeschulte and Seeger 2003; Femmer 2004). Future mining in the area has the potential to increase the risk of adverse environmental effects on the water quality and aquatic biota in nearby high-quality streams; the EA is located within the surface watershed of the Eleven Point River, a federally protected wild and scenic river, and the groundwater recharge of large springs that feed the Current River and Jacks Fork within the Ozark National Scenic Riverways, a National Park (Imes 2002; Imes et al. 2007). The area is characterized by subsurface stream flow and high-volume springs with large groundwater recharge areas, many of which are interconnected (Vinyard and Feder 1974; Imes et al. 2007). Because of these characteristics, heavy metals associated with future mining or exploratory drilling could have far-reaching adverse effects on water resources and biota (Kleeschulte 2000).

Lead contamination in southeastern Missouri has recently received more attention, both locally and nationally (Starnes and Gasper 1996; MDNR 2007). The transport of metal-enriched tailings into area streams has caused contamination of fish and other aquatic biota and public health advisories against human consumption of leadcontaminated fish (Czarneski 1985; Schmitt and Finger 1987; Schmitt et al. 1993; Besser et al. 2007; Schmitt et al. 2007a, b). The increased public concerns related to future adverse effects of mining on the water quality of streams located in this region prompted a series of multidisciplinary studies conducted by the US Geological Survey (USGS) that began in 2000 (Imes 2002). These studies included geological and hydrological investigations (Kleeschulte 2003; Kleeschulte and Seeger 2003), measuring effects of sediment contamination in laboratory toxicity tests (Besser et al. 2009), biological investigations related to macroinvertebrate communities (this study) and crayfish densities
(Allert et al. 2008), examination of biomarkers as indicators of fish exposure to metals (Schmitt et al. 2007a, b), and metal body burdens in aquatic biota such as fish, snails, crayfish, aquatic plant biomass, and freshwater invertebrates (Besser et al. 2007).

The structure and function of aquatic macroinvertebrate communities have been among the most widely used aquatic indicator components for measuring the effects of heavy metal contamination resulting from mining activities (Cain et al. 1992). Their sensitivity, relatively short life cycles, and representativeness as biomonitoring tools make macroinvertebrates well-suited as key indicators of injury to natural resources, foodweb transfer to higher trophic levels, alteration of system functions, and evaluations of overall water resource quality (Rosenberg and Resh 1993). Macroinvertebrates were being utilized as indicators of mining-related impacts in streams many years before the current emphasis on the development of biological assessment programs by state natural resource agencies. In the southeastern Missouri Ozark region, previous macroinvertebrate community assessments were conducted during the 1970s and 1980s, with alteration of both fish and macroinvertebrate communities attributed to mining of the Viburnum Trend during this period (Ryck 1974; Duchrow 1983). However, these earlier studies did not attempt to quantify the degree of stream impairment because implementation of biological assessment programs, identification of reference conditions, and subsequent development of biological criteria (USEPA 1990) have only recently been initiated for Missouri streams (Sarver et al. 2002). Further, many earlier studies were conducted during operation of older mines that have since been closed and replaced with newer facilities that include improved mine wastewater treatment methods, and some mines have changed their operational focus toward recycling and other forms of metal processing (Brumbaugh et al. 2007). This paper reports the results of the macroinvertebrate biological assessment conducted in 2003 and 2004 as part of the overall USGS study and assesses relative biological condition among stream sites with 
varying degrees of metal contamination, aquatic life attainment status of the sites, identification of stream impairment, and correlations between biological indicators and environmental variables.

\section{Materials and methods}

Study area

The state of Missouri has been divided into ecological drainage units (EDUs), each comprising multiple watersheds with similar aquatic communities and ecological features (Rabeni and Doisy 2000; Rabeni and Sowa 2002; Sowa et al. 2004, 2007). The MDNR has used these divisions to develop biological criteria for wadeable, perennial streams, and subsequent assignment of expected aquatic macroinvertebrate indicator values for these areas (Sarver et al. 2002; MDNR 2003). The Viburnum Trend and our sampling sites are located in two EDUs of the southeastern Missouri Ozarks; two sites were in the Meramec River EDU (HZ and CC), and 19 sites were in the Black River/Current River EDU (Fig. 1). Mining features in the area include mines, tailings, smelters, and settling basins used for clarification of mine wastewater effluent (Table 1). Metals enter the streams from intermittent discharges of mine process water, mine dewatering, and possibly by periodic seepage or release of fugitive dust from tailings or settling basins. Watershed areas upstream of the sampling sites vary in characteristics such as the area occupied by tailings and distances that mining activities are located upstream (Table 1).

Aquatic macroinvertebrate communities were sampled at 20 sites in August of 2003 and 2004, eight of which were sampled during both years (Table 1). Two sites (BC and SK) have been designated by the state of Missouri as reference sites, which are defined as those with the least amount of human influence within an individual EDU. One additional site (GRS), located in the EA (Fig. 1), was sampled seasonally in 2002 and 2003 with the same macroinvertebrate methods, as part of an extensive survey of the aquatic fauna inhabiting the Greer Spring branch. With the exception of this first-order spring branch (daily discharge = $187 \mathrm{mgd}$, Vinyard and Feder 1974), all sites were third- and fourth-order high gradient perennial streams with distinct riffle-pool sequences. All sites contained gravel-cobble as the predominant epifaunal substrate type.

Macroinvertebrate sampling procedure

Macroinvertebrates were collected utilizing the MDNR (2003) macroinvertebrate assessment protocol, which is a multihabitat sampling effort used for evaluating aquatic life status in Missouri streams. However, we used a modified version of this protocol and sampled only the single habitat of coarse substrate in riffle areas. Selection of this habitat for sampling is similar to the "richest targeted habitat" approach used by the National Water Quality Assessment Program of the US Geological Survey (Cuffney et al. 1993). At our 21 study sites, one composite kick net sample was taken from cobble and gravel substrates in riffles. Each sample consisted of disturbing two separate $1 \mathrm{~m}^{2}$ areas immediately upstream of a rectangular kick net $(23 \times 46 \mathrm{~cm})$ from each of three riffles within the study reach. Triplicate composite samples were taken at two of the sites in 2004, one with known elevated levels of heavy metals and one reference location. All composite samples were placed in 1-L jars and preserved with $90 \%$ ethanol.

Aquatic macroinvertebrate samples were subsampled in the laboratory with a gridded tray, applying a fixed-count method where grids were chosen and sorted randomly until at least 600 organisms were obtained, as described in the state assessment protocol (MDNR 2003). Organisms were identified and enumerated to the lowest practical taxonomic level, usually genus or species. Midge larvae (Diptera: Chironomidae) were mounted on glass slides with CMCP-10 mounting media (Masters Chemical Co, Des Plaines, IL, USA) and allowed to clear for at least one month before identification to genus. During enumeration and identification of organisms, terrestrial 
adults, zooplankton, and Oligochaeta worms in the family Naididae were omitted from the data before analyses, as per the Missouri bioassessment protocol (Sarver and McCord 2005; MDNR 2003).

\section{Environmental variables}

A total of 14 environmental variables were measured at the macroinvertebrate sampling sites in both 2003 and 2004 as part of the overall study. These included concentrations of four metals in pore water $[\mathrm{Pb}, \mathrm{Cadmium}(\mathrm{Cd}), \mathrm{Zn}$, and nickel $(\mathrm{Ni})$ in milligrams per/liter], the pore water toxic units computed from the concentrations of these metals (Wildhaber and Schmitt 1996), four substrate variables ( $\%$ embeddedness and \% of three substrate size classes), $\mu \mathrm{mhos} / \mathrm{cm}$ (micromhos per centimeter), two water temperature variables (median and maximum in ${ }^{\circ} \mathrm{C}$ ), and two riparian habitat variables (percent bank cover, and percent canopy cover). In 2003, pore water samples were collected with membrane "peeper" samplers, which consisted of $30 \mathrm{ml}$ polypropylene bottles that were filled with deionized water and capped with a $0.45-\mu \mathrm{m}$ filter (Brumbaugh et al. 2002). These passive diffusion samplers were deployed in riffle substrates for one month at each site. In 2004, stream sediments were pumped and allowed to settle, and pore water was extracted in the laboratory by centrifugation (Brumbaugh et al. 2007). Determination of all metals concentrations in these samples and those measured during the overall study are described by Brumbaugh et al. (2007) and Besser et al. (2009). The toxic units variable represented a method to estimate the risk associated with the cumulative toxicity of metals ( Pb, Cd, Zn, Ni; Wildhaber and Schmitt 1996). Toxic units are the measured concentration of each dissolved metal in pore water relative to its chronic water quality criterion (USEPA 2002) adjusted as necessary for hardness. Toxic units for individual metals are summed to produce an integrated toxicity estimate or score for each sample, with values greater than one considered to represent a risk of toxicity to sediment-dwelling biota (Wildhaber and Schmitt 1996).

Substrate embeddedness was estimated by visual examination of five to seven randomly selected cobbles (a total of 20 per site) removed by hand from each available riffle (Platts et al. 1983). Heterogeneity of stream substrate size classes was determined by underwater visual examination through a $45 \times 60-\mathrm{cm}$ rectangular sheet of transparent plastic placed on the water surface to reduce glare and enhance the visibility of bottom substrates (USEPA 1983; Hamilton and Bergersen 1984). This substrate estimate was made at five randomly selected locations in each available riffle adjacent to where the benthic macroinvertebrate samples were collected. These size classes included cobble and boulder (>64 mm), fine to coarse gravel $(2-64 \mathrm{~mm})$, and particles in the sand-silt-clay range $(<2 \mathrm{~mm})$. Surface water temperature data were also collected hourly for 15 consecutive days in September 2003 and 2004 with Onset ${ }^{\circledR}$ Temppro (Pocassset, MA, USA) data loggers deployed at each site. Specific conductance was measured concurrently with macroinvertebrate and sediment collections with a portable Hydrolab ${ }^{\circledR}$ Quanta meter that was calibrated daily and corrected for temperature. Percent bank cover was estimated visually on right and left banks at three to five transects marked in each of the riffle areas at the sites, using a method described by Ball (1982) and Barbour et al. (1999). Percent canopy cover was measured with a densitometer at the same riffle transects using a method described by Bain and Stevenson (1999) and averaged for each site.

\section{Analyses of data}

Macroinvertebrate sample data were used to derive eight metric values for the sites (Table 2). Metrics included four core metrics used to calculate the Stream Condition Index (SCI) for determining impairment status of Missouri streams (Sarver et al. 2002) and four additional metrics in which response patterns were observed in relation to the gradient in levels of metals across all sites (Table 2). These additional metrics included one structural metric (\% Chironomidae), one dominance metric ( $\%$ dominant taxon), one functional metric ( $\%$ scrapers), and one tolerance metric (tolerant/intolerant mayfly ratio). In this study, the ratio of tolerant/intolerant mayflies 
Table 2 List of benthic macroinvertebrate metrics included in two separate multimetric indices used to evaluate 21 stream sites in the Ozark region of southeastern Missouri and expected response to mining-related disturbances

\begin{tabular}{|c|c|c|c|}
\hline \multirow[t]{2}{*}{ Metric name and reference } & \multicolumn{2}{|c|}{ Metrics included } & \multirow{2}{*}{$\begin{array}{l}\text { Expected response } \\
\text { to mining activities }\end{array}$} \\
\hline & $\mathrm{SCI}^{\mathrm{a}}$ & Biotic condition score & \\
\hline Taxa richness (Barbour et al. 1999) & $\mathrm{X}$ & $\mathrm{X}$ & Decrease \\
\hline EPT richness (Klemm et al. 1990) & $\mathrm{X}$ & $\mathrm{X}$ & Decrease \\
\hline Missouri biotic index (Sarver and McCord 2005) & $\mathrm{X}$ & $\mathrm{X}$ & Increase \\
\hline Shannon-Wiener diversity index (Washington 1984) & $\mathrm{X}$ & $\mathrm{X}$ & Decrease \\
\hline Percent (\%) Chironomidae (Hayslip 1993) & & $\mathrm{X}$ & Increase \\
\hline Percent (\%) dominant taxon (Shackleford 1988) & & $\mathrm{X}$ & Increase \\
\hline Percent (\%) scrapers (Barbour et al. 1999) & & $\mathrm{X}$ & Decrease \\
\hline Tolerant/intolerant Ephemeroptera ratio (Applegate et al. 2007) & & $\mathrm{X}$ & Increase \\
\hline
\end{tabular}

SCI Stream Condition Index

${ }^{\text {a }} \mathrm{SCI}$ calculated based on criteria for a single habitat (coarse substrate in riffle areas)

(Ephemeroptera) metric was determined by relative abundance of mayflies with Missouri Biotic Index (MoBI) tolerance values (Sarver and McCord 2005) of 5.0 or greater divided by relative abundance of mayflies with MoBI tolerance values less than 5.0. Other metrics examined were eliminated from further analysis due to redundancy, or because no response to elevated concentrations of metals was evident.

Metric values were used to calculate two separate multimetric indices: (1) a modified SCI and (2) a macroinvertebrate site score that integrates all eight response metrics (biotic condition score). Calculation of the multihabitat SCI for Missouri is based on MDNR-recommended criteria that were determined from metric performance and expectations at regional reference stream sites $(1=$ below range bisection value; $3=$ between upper quartile and range bisection values; $5=$ above upper quartile value) for the EDU in which a site is located. However, criteria can also be calculated for a single habitat in situations where the objective of a stream biological assessment is to isolate the effects of water quality impairments rather than those that might be caused by habitat degradation or loss. For this study, we calculated a modified single-habitat SCI using the same four core metrics (Table 2) and scoring framework, but for each metric, we relied on criteria values for coarse substrate in riffles only. Stream sites were placed into categories of aquatic life impairment status based on the following ranges in singlehabitat SCI scores: (1) 16-20 = fully-supporting, (2) $10-14=$ partially supporting, and (3) $4-8=$ nonsupporting (Sarver et al. 2002). The macroinvertebrate biotic condition score that included all eight response metrics was determined by proportional scaling of metric values from 1-100 across all sites (Kreis 1988) and adding all scores of individual metrics to obtain one overall site score to represent relative biotic condition. Based on these biotic condition scores, sites were ranked from best to worst for each year separately.

All statistical analyses were performed with release 9.1 of the Statistical Analysis System for Windows (SAS Institute, Cary, NC, USA). To identify statistically significant differences among sites, the sampling sites were grouped into two independent sets of categories. These separate site groupings included (1) three categories separated based on mining activity (presence or absence, distance upstream, and surface area or percent of watershed area) in relation to location of the sampling sites (Table 1) and (2) three categories separated by ranks and relative percentages of biotic condition scores in relation to the highest score obtained from one of the state-designated reference sites (BC or SK). For this study, the three mining activity categories were defined as reference $(\mathrm{R}=$ no mining in watershed, or tailings or mine(s) located $20 \mathrm{~km}$ or more upstream of site), downstream ( $\mathrm{D}=\operatorname{mine}(\mathrm{s})$ and/or tailings 10-19.9 km upstream of site, or if $<10 \mathrm{~km} \mathrm{up}$ stream, percent of watershed in tailings is $<0.6 \%$ ), and mining $(\mathrm{M}=$ mine(s) and/or tailings $<10 \mathrm{~km}$ upstream of site, or tailings area $>1.34 \mathrm{~km}^{2}$ in watershed). Site categories based on biotic condition scores in relation to reference sites included the 
following: (a) sites with scores above $75 \%$ of reference maximum and among top four sites in rank, in one or both years, (b) sites with intermediate scores and ranks, and (c) sites with scores below $75 \%$ of reference maximum or among bottom four sites in rank, in one or both years. Statistical comparisons were made between category means for macroinvertebrate biotic condition scores and for each of the 14 environmental variables described above, using discriminant function analysis $(\alpha=0.05$ significance level). These analyses were performed independently for each type of site grouping (mining categories and biotic condition score categories). A stepwise multiple regression (PROC STEPWISE) was performed on these data to identify the most important variable for predicting the assignment of a study site to a particular category. The forward selection method was used, with variables allowed into the model only if they significantly reduced the unexplained sum of squares after accounting for all other variables in the model. A significance level of $\alpha=0.15$ was used to avoid discarding metrics too early during the stepwise procedure. Both of these analyses were performed independently for each of the two sampling years.

Correlation coefficients (Spearman, $\alpha=0.05$ ) between the site ranks of the 14 environmental variables and macroinvertebrate biotic condition scores were computed to quantify the strength of association between environmental conditions and macroinvertebrate response. These analyses were performed independently for each sampling year, to identify the variables that had the strongest relations with the gradient in relative biological conditions as indicated by ranks in macroinvertebrate scores. For each year, data for each variable that generated at least one significant correlation with biotic condition scores were also used to perform a cluster analysis (PROC CLUSTER) to help identify and/or confirm meaningful groupings of the sites and site similarity. Nonparametric analysis of variance (ANOVA; Kruskal-Wallis) was used to identify statistical significance in biotic condition scores between individual sites in reference, downstream, and mining categories. Because replicate samples were only taken at two sites (one reference and one mining-impacted), a pooled standard error for these sites was applied to all sites by year separately before this analysis $(\alpha=0.05)$.

\section{Results}

Community structure

Collectively, a total of 137 macroinvertebrate taxa were present at the sampling sites, including 45 Ephemeroptera-Plecoptera-Trichoptera (EPT) taxa and 35 midge (Diptera: Chironomidae) taxa. The dominant EPT taxa at most sites included the mayflies Stenonema and Stenacron (Heptageniidae), Isonychia (Isonychiidae), Serratella (Ephemerellidae), the stonefly Leuctra (Leuctridae), and the caddisfly Cheumatopsyche (Hydropsychidae). The most upstream site on Strother Creek (SC2) was the only study site at which no stoneflies (Plecoptera) were present in either sampling year, and the most dominant EPT taxon was the tolerant mayfly Tricorythodes (Tricorythidae) in both years.

\section{Metric response}

Across study sites, total taxa richness ranged from 28 to 57 and EPT richness ranged from 7 to 27 . For total taxa richness, the highest was at Greer Spring (GRS) in 2003 and the lowest were at sites LC in 2003 and WF2 in 2004. For EPT richness, the highest was at GRS in 2003 and the lowest was at site SC2 in both years ( $n=9$ in 2003, $n=7$ in 2004). The MoBI ranged from 3.97 to 5.49 in 2003 and 3.69 to 5.74 in 2004. Missouri Biotic Index values were the lowest at GRS in 2003 and MF2 in 2004. The Shannon-Wiener diversity index ranged from 1.85-3.13, with the lowest values found at site SC2 in both years.

Among the four additional metrics included in the biotic condition score, percent Chironomidae ranged from $2.6 \%$ to $20.6 \%$ in 2003 and $0.6 \%$ to $11.5 \%$ in 2004 , with the highest values at mining sites SC2 (2003) and BF4 (2004). Percent dominant taxon ranged from $12.2 \%$ to $58.5 \%$ in 2003 and $14.5 \%$ to $41.1 \%$ in 2004 , with the highest values found at the upper Strother Creek site (SC2). Percentage of the scraper functional group ranged from $1.8 \%$ (SC2) to $44.0 \%$ (GRS) in 2003 
and from $2.6 \%$ (SC2) to $40.4 \%$ (MF2) in 2004. The tolerant/intolerant mayfly ratio ranged from 0.04 to 0.97 in 2003 and 0.10 to 0.99 in 2004 , with the highest values found at site SC2 in both years.

\section{Environmental variables}

Environmental variables were measured to determine the most important factors that may be influencing differences in aquatic macroinvertebrate communities among sites. In general, metal ion concentrations in sediment pore water were the lowest at reference sites, the highest at mining sites, and intermediate at sites located a greater distance downstream from mining. Concentrations of $\mathrm{Cd}, \mathrm{Ni}, \mathrm{Pb}$, and $\mathrm{Zn}$ in pore water, surface water, and stream sediments are reported by Brumbaugh et al. (2007) and Besser et al. (2009). Concentrations of $\mathrm{Cd}, \mathrm{Pb}, \mathrm{Ni}$, and $\mathrm{Zn}$ in foodweb components (invertebrates, fish, and plant biomass including algae and periphyton) that were sampled at the macroinvertebrate sites are also reported by Besser et al. (2007); our upper sites on Bee Fork (BF4) and Strother Creek (SC2) are given as "BF" and "ST" within this publication. Values for pore water toxic units calculated from sediment pore waters extracted from membrane peepers (2003) and pumped sediments (2004) are reported in Brumbaugh et al. (2007) and Besser et al. (2009). Data for the remaining nine environmental variables are given in Tables 3 and 4. Except for the metals concentrations, only three other environmental variables that we measured concurrently with macroinvertebrate sampling were significantly correlated with biotic condition scores. These included percentage of small substrate size classes $<2 \mathrm{~mm}$ (range of means $14-39 \%$ in 2003 and $11-43 \%$ in 2004), percentage of substrate embeddedness (range of means $28-61 \%$ in 2003 and $30-57 \%$ in 2004 ), and specific conductance of surface water (range in means of $214-854 \mu \mathrm{mhos} / \mathrm{cm}$ in 2003 and 294$907 \mu \mathrm{mhos} / \mathrm{cm}$ in 2004).

\section{Biotic condition and impairment}

The SCI placed three sites in the R category as fully supporting of aquatic life in both years (WF1,

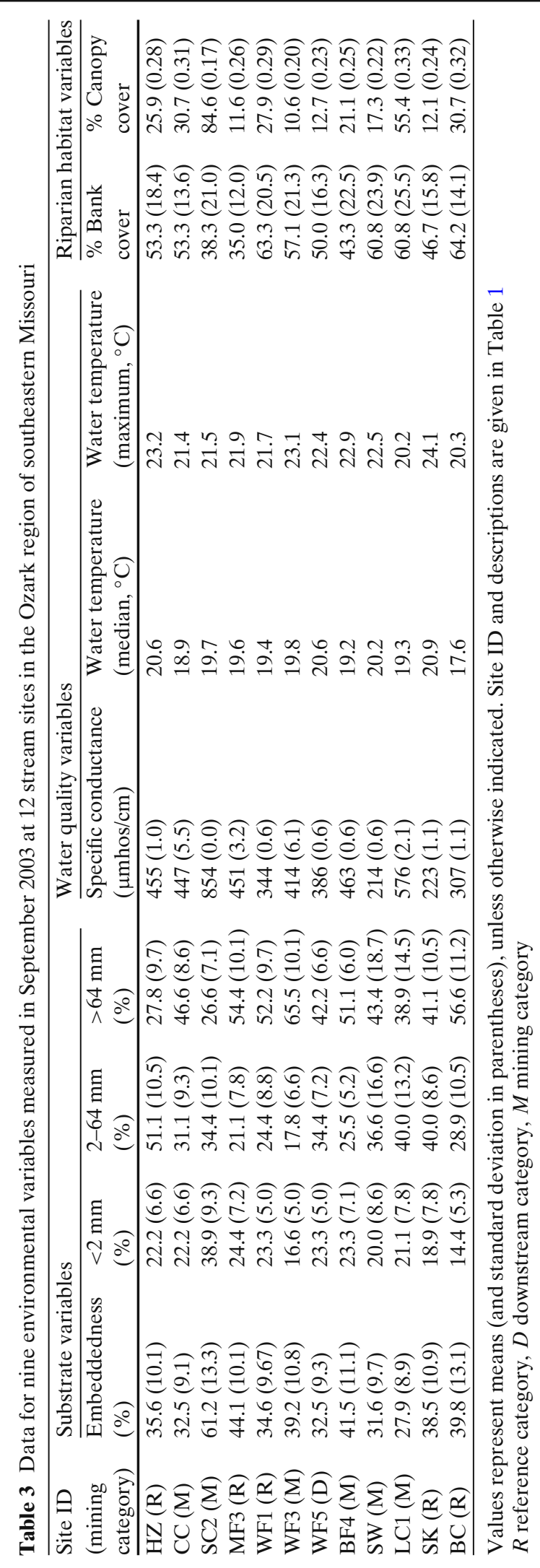




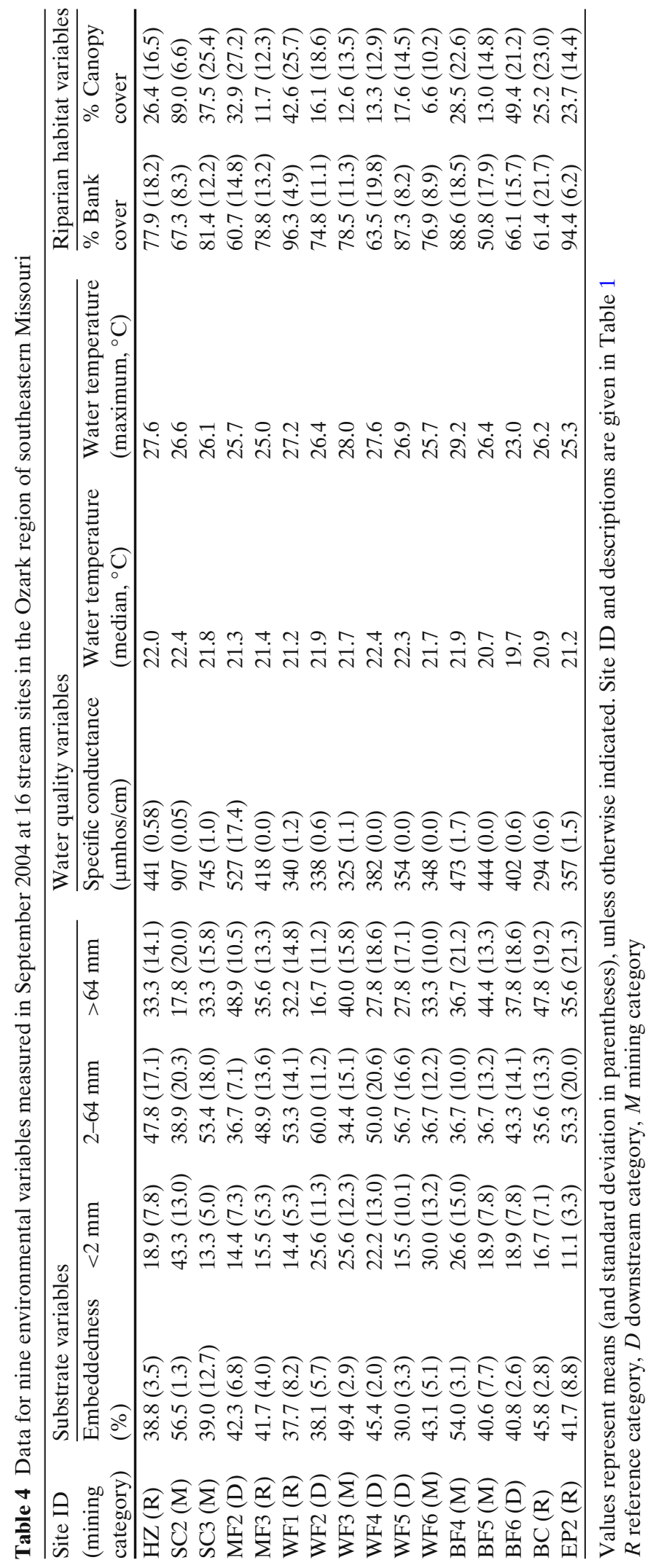


BC, HZ; Fig. 2). Among the 13 sites sampled in 2003, nine were partially supporting; seven of these $(77 \%)$ were downstream of mining areas (categories D or M). Of the 16 sites sampled in 2004, seven of the sites downstream of mining areas (categories D and M) were fully supporting (Fig. 2). Considering both years, the maximum biotic condition score among the two state reference sites was observed at Blair Creek (BC) in 2004. Sites directly below mining (category M) with the highest concentrations of pore water metals on West Fork Black River (WF3), Bee Fork (BF4), and Strother Creek (SC2) were partially supporting of aquatic life in one or both years (Fig. 2) and had biotic condition scores below $75 \%$ of the maximum score attained by the reference site at Blair Creek (Fig. 3). The Eleven Point River (EP2) and Sinking Creek (SK) sites scored lower than expected and were the only sites in the R category that were partially supporting (Fig. 2) and below $75 \%$ of the maximum biotic condition score (Fig. 3) at the Blair Creek (BC) reference site.

As compared to reference sites, sites directly below mining areas had significantly lower mean biotic condition scores in 2003. Sites in this category had mean biotic condition scores that were from $10 \%$ to $58 \%$ lower than reference sites. Sites in the category with the lowest ranks in biological condition (category C) had significantly lower mean scores in both years (Table 5). In 2004, mean estimates of both percent fine substrate $(<2 \mathrm{~mm})$ and percent embeddedness were significantly higher at $\mathrm{M}$ sites, and the mean estimate of percent embeddedness was significantly higher at sites in the category with the lowest biological condition scores (category C; Table 5). Ranks of biotic condition scores across sites were significantly correlated with ranks of specific conductance and the four pore water metals in $2003(\mathrm{Cd}, \mathrm{Ni}, \mathrm{Pb}$, $\mathrm{Zn}$ ) and with $\mathrm{Cd}, \mathrm{Pb}$, and pore water toxic units in 2004 (Table 5). The variables most important in

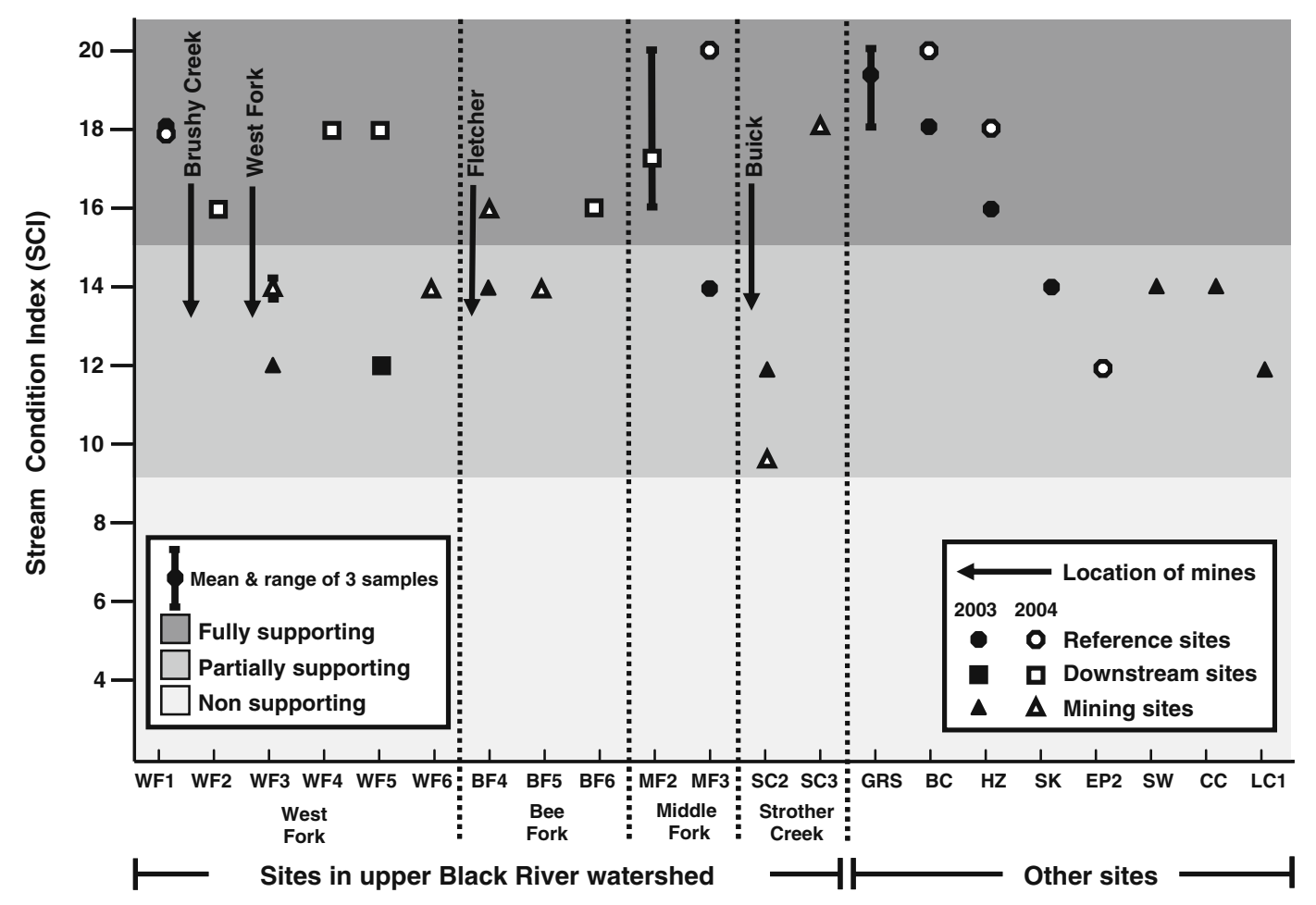

Fig. 2 Aquatic life support status for 21 stream sites in the southeastern Missouri Ozark region based on the Stream Condition Index (single habitat SCI) and placement of sites into three categories defined by mining activity (Fig. 1).
Description of mining activity and site identifications are given in Table 1, and definitions of site categories are given in the text 


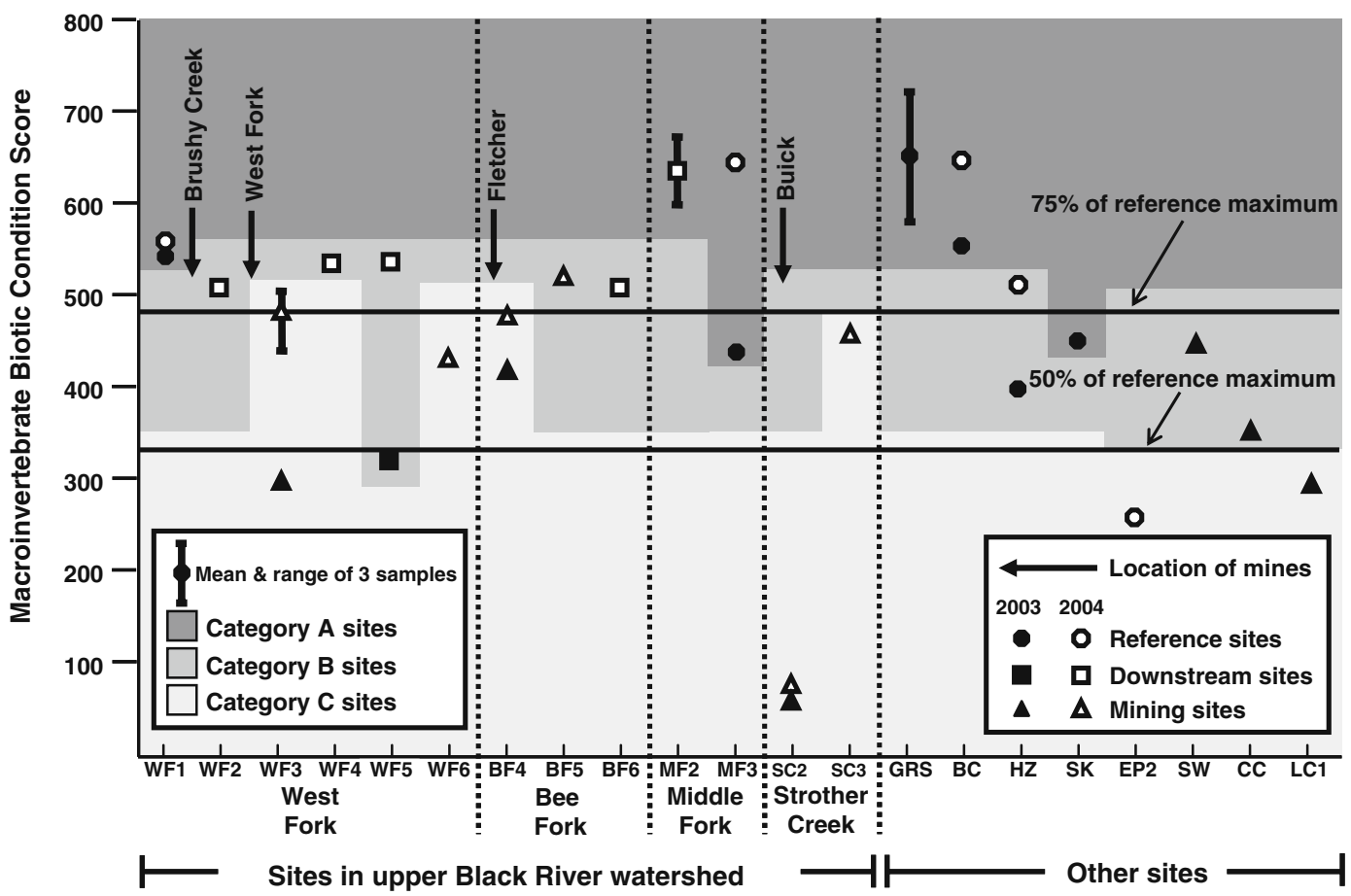

Fig. 3 Macroinvertebrate biological condition scores for 21 stream sites in the southeastern Missouri Ozark region and placement of sites into three biotic condition cate-

separating categories of sites or predicting site placement in a particular category included sediment pore water $\mathrm{Cd}$ and $\mathrm{Pb}$ in 2003 and sediment pore water $\mathrm{Ni}$ and $\mathrm{Pb}$ in 2004 (Table 5). Among the 2003 biotic condition scores, one mining site (SC2) was significantly lower than reference site scores at Blair Creek (BC), upper West Fork (WF1), or both. In 2004, four M and D sites (WF3, WF5, BF4, SC2) had significantly lower biotic condition scores than reference sites WF1, BC, or both (Fig. 4). The highest biotic condition scores were at Greer Spring (GRS), which is located within the EA and Mark Twain National Forest. This site also had the highest total $(n=53)$ and EPT $(n=28)$ taxa richness among all sites.

Cluster analysis including the environmental variables and biotic condition scores provided some confirmation that sites were placed into ecologically relevant groups based on their characteristics. In 2003, SC2 was widely separated from other sites (Fig. 5a), and in 2004, three sites in the $\mathrm{M}$ category grouped together as one cluster (Fig. 5b). Most sites in the R category clustered gories representing relative degree of biological impacts. Site identifications are defined in Table 1

separately from sites directly below mining. The most notable exception to this pattern was site MF3 (Fig. 5), which grouped with two sites in the mining category in 2003 (WF3, BF4) and three sites belonging to different categories (one site each) in 2004 (WF4, WF6, HZ).

\section{Discussion}

Adverse effects of lead-zinc mining and related activities on aquatic macroinvertebrates within watersheds located in the New Lead Belt were documented in the 1970s and 1980s (Ryck 1974; Duchrow et al. 1980; Duchrow 1983). During this period, the suspected causes of water quality degradation associated with lead-zinc mines included catastrophic or intermittent releases from tailings or settling ponds during heavy rainfall events (USEPA 1994). During the late 1960s and 1970s, new techniques were developed to improve metals recovery and the treatment of mine wastes, including passive wastewater treatment systems 
Table 5 Summary of significant differences in site category means, and rank correlations between macroinvertebrate biotic condition scores and eight environmental variables, for 21 southeastern Missouri Ozark stream sites sampled in 2003 and 2004

\begin{tabular}{|c|c|c|c|c|c|c|c|c|c|c|}
\hline \multirow[t]{2}{*}{ Year/variable } & \multicolumn{4}{|c|}{$\begin{array}{l}\text { Site category based on } \\
\text { mines and tailings }\end{array}$} & \multicolumn{4}{|c|}{$\begin{array}{l}\text { Site category based on } \\
\text { biotic condition score }\end{array}$} & \multicolumn{2}{|c|}{$\begin{array}{l}\text { Rank correlation with } \\
\text { biotic condition score }\end{array}$} \\
\hline & $\mathrm{R}$ & $\mathrm{D}$ & M & $\operatorname{Pr}>F$ & A & B & $\mathrm{C}$ & $\operatorname{Pr}>F$ & $r$ value & Significance \\
\hline \multicolumn{11}{|l|}{2003} \\
\hline Biotic condition score & $\mathrm{a}$ & $\mathrm{ab}$ & $\mathrm{b}$ & 0.05 & $\mathrm{a}$ & $\mathrm{ab}$ & $\mathrm{b}$ & $0.03 *$ & & \\
\hline $\mathrm{Cd}$ in pore water & $\mathrm{a}$ & $\mathrm{a}$ & $\mathrm{a}$ & 0.13 & a & a & $\mathrm{a}$ & $0.22 *$ & -0.61 & 0.03 \\
\hline $\mathrm{Ni}$ in pore water & a & a & $\mathrm{a}$ & 0.29 & $\mathrm{a}$ & $\mathrm{a}$ & $\mathrm{a}$ & 0.27 & -0.62 & $\mathbf{0 . 0 3}$ \\
\hline $\mathrm{Pb}$ in pore water & $\mathrm{b}$ & b & $\mathrm{a}$ & $0.001 *$ & $\mathrm{~b}$ & ba & $\mathrm{a}$ & $0.01 *$ & -0.64 & 0.02 \\
\hline $\mathrm{Zn}$ in pore water & $\mathrm{a}$ & $\mathrm{a}$ & $\mathrm{a}$ & 0.06 & $\mathrm{a}$ & $\mathrm{a}$ & $\mathrm{a}$ & 0.17 & -0.63 & 0.02 \\
\hline Specific conductance & $\mathrm{b}$ & $\mathrm{b}$ & $\mathrm{a}$ & 0.08 & $\mathrm{~b}$ & ba & $\mathrm{a}$ & 0.08 & -0.68 & 0.01 \\
\hline \multicolumn{11}{|l|}{2004} \\
\hline Biotic condition score & $\mathrm{a}$ & $\mathrm{a}$ & $\mathrm{a}$ & 0.33 & $\mathrm{a}$ & $\mathrm{a}$ & $\mathrm{b}$ & $0.006 *$ & & \\
\hline Percent fine substrate $(<2 \mathrm{~mm})$ & $\mathrm{b}$ & ba & $\mathrm{a}$ & 0.07 & a & a & $\mathrm{a}$ & 0.19 & -0.39 & 0.13 \\
\hline Percent substrate embeddedness & $\mathrm{b}$ & ba & $\mathrm{a}$ & 0.05 & $\mathrm{~b}$ & $\mathrm{~b}$ & $\mathrm{a}$ & 0.06 & -0.27 & 0.30 \\
\hline $\mathrm{Cd}$ in pore water & a & $\mathrm{a}$ & $\mathrm{a}$ & 0.10 & $\mathrm{~b}$ & $\mathrm{~b}$ & $\mathrm{a}$ & 0.03 & -0.55 & 0.02 \\
\hline $\mathrm{Ni}$ in pore water & $\mathrm{b}$ & ba & $\mathrm{a}$ & $0.04 *$ & $\mathrm{~b}$ & $\mathrm{~b}$ & $\mathrm{a}$ & 0.01 & -0.37 & 0.15 \\
\hline $\mathrm{Pb}$ in pore water & $\mathrm{a}$ & a & a & 0.12 & $\mathrm{a}$ & $\mathrm{a}$ & $\mathrm{a}$ & $0.09 *$ & -0.57 & 0.02 \\
\hline $\mathrm{Zn}$ in pore water & $\mathrm{b}$ & ba & $\mathrm{a}$ & 0.06 & $\mathrm{~b}$ & $\mathrm{~b}$ & $\mathrm{a}$ & 0.03 & -0.44 & 0.08 \\
\hline Pore water toxic units & $\mathrm{a}$ & $\mathrm{a}$ & $\mathrm{a}$ & 0.39 & $\mathrm{a}$ & $\mathrm{a}$ & $\mathrm{a}$ & 0.52 & -0.57 & 0.02 \\
\hline
\end{tabular}

Category means with the same letter are not significantly different; within categories, means are listed alphabetically from highest (a) to lowest (b). Rank correlations (Spearman, $\alpha=0.05$ ) and differences among site category means (discriminant function, $\alpha=0.05)$ that are statistically significant are indicated by values in bold

$R$ reference category, $D$ downstream category, $M$ mining category

*Selected as most important variable(s) for predicting category assignment of sites (stepwise, $\alpha=0.15$ model acceptance criteria)

with increased retention time and recycling of wastewater from mining and beneficiation. Ryck (1974) reported that most mines began recycling mill wastes on a permanent basis after September 1971. Studies conducted during this period reported some amelioration of adverse effects on stream biota after these techniques were implemented (Ryck and Whitley 1974; Wixson 1977). Since 1980, some mining facilities have either expanded, become inactive, or converted to other forms of metal processing, including recovery of metals from previously used consumer products such as batteries (Brumbaugh et al. 2007). At present, some mines continue to extract metal ores under stricter environmental controls.

Mayflies and stoneflies are among the most sensitive macroinvertebrate groups to heavy metals contamination in streams (Burrows and Whitton 1983; Kiffney and Clements 1994). However, there is some indication that their tolerances to metals may be partially $\mathrm{pH}$ dependent (Feldmann and Connor 1992). Species richness

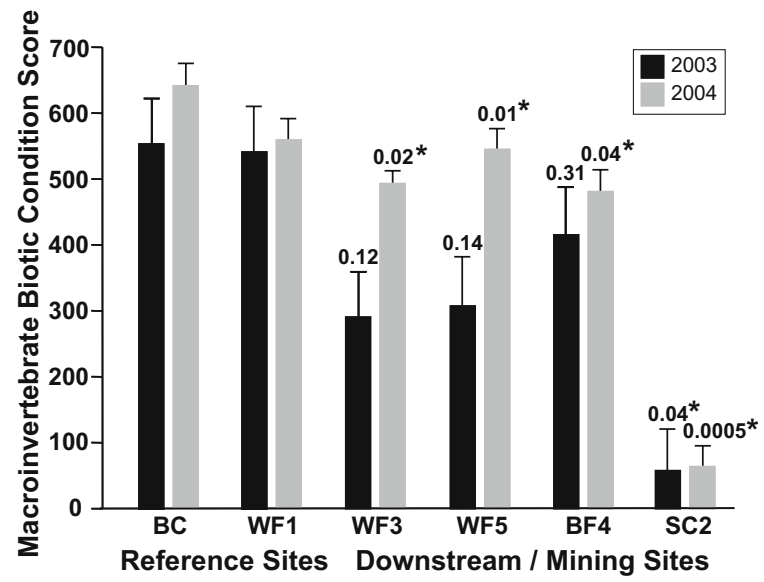

Fig. 4 Significant differences in macroinvertebrate biotic condition scores between selected sites in reference, downstream, and mining categories for 2003 and 2004 sampling years. Only sites with scores that generated at least one significant difference with a reference site are shown. Pooled standard error (bars) from replication sites was applied to all sites by year separately before analysis (nonparametric ANOVA, $\alpha=0.05)$. $P$ values with an asterisk indicate a statistically significant difference from reference sites. Site identifications are defined in Table 1 
Fig. 5 Results of cluster analysis performed on 21 macroinvertebrate sampling sites (with mining category in parentheses) for a 2003 and b 2004. Site identifications are defined in Table 1. Mining categories: $R$ reference, $D$ downstream, $M$ mining

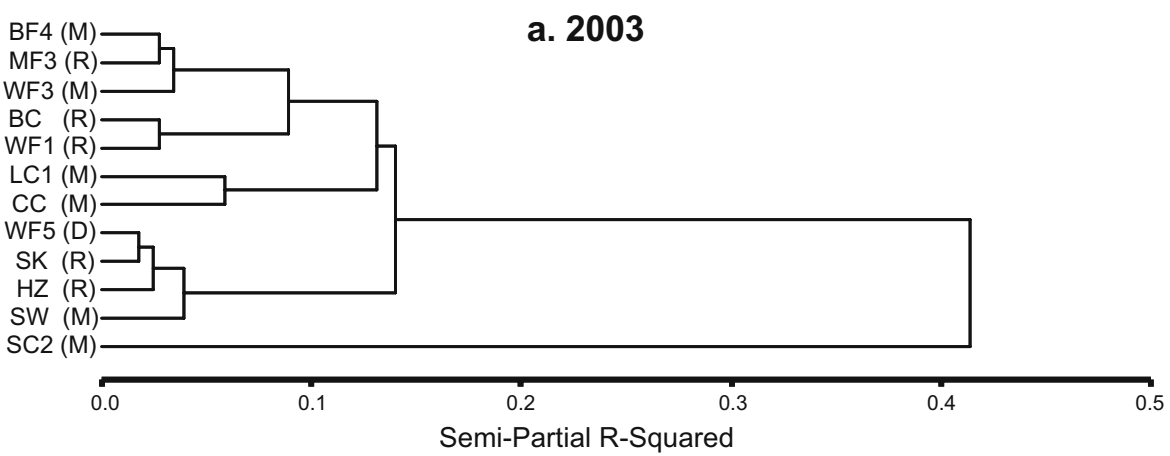

b. 2004

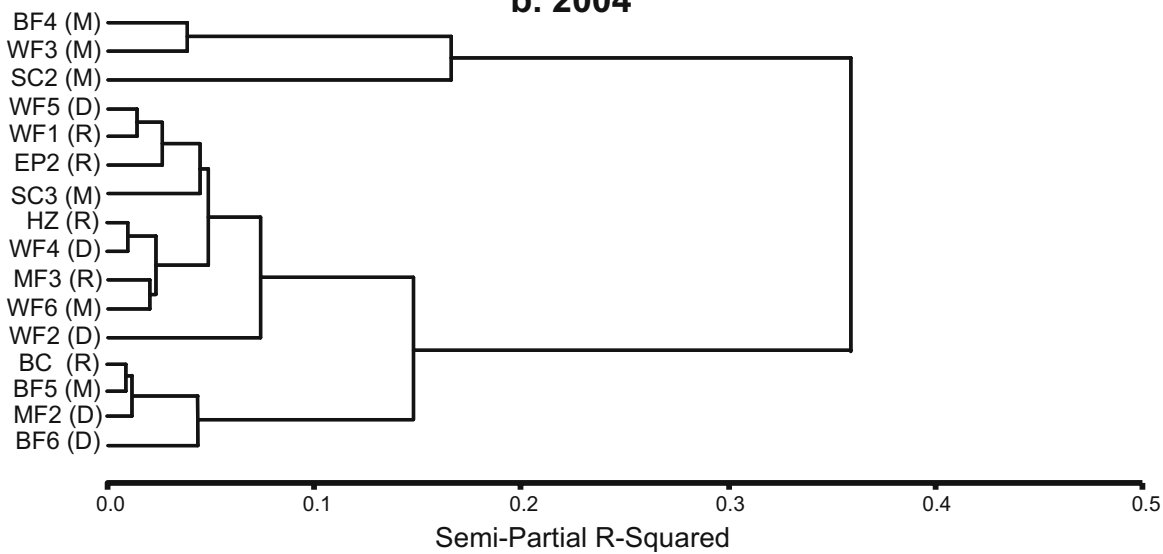

metrics such as total and EPT taxa richness are among the best indicator metrics for detecting these impacts (Soucek et al. 2000; Clements et al. 2000). A decrease in total macroinvertebrate taxa richness and the number of mayfly and stonefly taxa between pre- and postmining periods was previously reported in the same reaches of Bee Fork and Strother Creek that included our sites BF4 and SC2, respectively (Ryck 1974). During our study, these macroinvertebrate indicators fell within the same ranges as the postmining values reported earlier; number of mayfly and stonefly taxa ranged from seven to nine at the upper Bee Fork site (BF4), and only four taxa in these groups were present at the upper Strother Creek site (SC2) in both sampling years. Duchrow (1983) outlined recommended minimum criteria for number of mayfly and stonefly taxa in Missouri streams, based on regression analysis of 895 stream samples. Their recommendation $(>9$ taxa $=$ unpolluted, 5-9 taxa $=$ moderately pol- luted, and $<5$ taxa $=$ polluted) would place SC2 in the polluted category and most other $\mathrm{M}$ sites examined in this study as moderately polluted based on our data.

Effects on macroinvertebrate communities were not evident at some sites located downstream of mines and mining-related facilities. The two sampling locations on the Middle Fork Black River (MF2, MF3) had among the highest relative biological condition scores (top four in rank in one or both years), even though elevated levels of metals in food-web organisms have been detected at MF3 (listed as site MF2 in Besser et al. 2007). As compared to reference sites, there were no significant differences in the biotic condition scores at sites on Huzzah Creek (HZ), Courtois Creek (CC), and Logan Creek (LC1), possibly because mines in these watersheds have been closed for many years. However, when these mines were active, species richness and diversity had declined at sites within these drainages. For example, 
number of mayfly and stonefly taxa dropped below five within the first month of mining activity in the Logan Creek (LC) watershed, and mining activities also reduced these taxa in Huzzah Creek and in Indian Creek just upstream of our site CC (Ryck 1974). During the present study, sites CC and LC1 had lower EPT taxa richness than reference sites and were placed in the partially supporting category based on SCI scores (Fig. 2). These results support the conclusions of other studies that have recognized the value of EPT metrics as indicators of metals toxicity in streams (Carlisle and Clements 1999; Soucek et al. 2000).

Available information on water and sediment quality parameters suggests that mining-related effects on macroinvertebrate communities are occurring at some, but not necessarily all, of the sites that are associated with environmental exposure to heavy metals. During this study, elevated concentrations of metals in sediment pore water exceeded water quality criteria (USEPA 2002) for $\mathrm{Pb}$ at ten sites (WF2, WF3, WF4, WF6, BF4, $\mathrm{BF} 5, \mathrm{BF} 6, \mathrm{MF} 3, \mathrm{SC} 2, \mathrm{SC} 3)$ and that for $\mathrm{Ni}$ at four sites (WF3, BF4, SC2, SC3). The stepwise regression analysis selected $\mathrm{Pb}$ concentrations in sediment pore water as one of the most important parameters for categorizing sites (Table 5). Further, concentrations of metals in sediment pore water and associated parameters related to concentrations of overall metal ions in surface water resulted in the most highly significant correlations with ranks in biotic condition scores (Table 5) in both 2003 (specific conductance, $\mathrm{Zn}, \mathrm{Pb}$ ) and 2004 ( Pb, toxic units). Both WF3 and SC2 were in the partially supporting category in both years, and sites SW, CC, and LC1 were partially supporting in 2003, indicating that these sites are biologically impaired. However, among the sites that were sampled in both years, one site each on West Fork of the Black River (WF5), Bee Fork (BF4), and Middle Fork of the Black River (MF3) were assigned to different impairment categories between the two sampling years (Fig. 2). The conclusion that these sites may be impaired is supported by mortality in laboratory toxicity tests with Hyallela azteca (Besser et al. 2009), reduced densities of crayfish (Orconectes hylas; Allert et al. 2008), and elevated body burdens in snails, crayfish, benthos, algae, and the blood and liver of fish (Besser et al. 2007; Schmitt et al. 2007a, b). Collectively, these indicators also imply that West Fork site WF6 and Bee Fork site BF5 are also impaired. Besser et al. (2007) suggested that higher stream discharges during the months preceding the 2004 sampling may have resulted in lower concentrations of metals in food web organisms collected that year, as compared to those from samples taken in 2002 at the end of an extended drought period. This conclusion is also substantiated by our macroinvertebrate biotic condition scores, which were higher at some sites in 2004 than in 2003 (Fig. 3). In addition, the MDNR documented low SCI scores and partially supporting aquatic life status from multiple sites in the Courtois Creek watershed sampled in 2001-2002, including our site CC (Humphrey and Lister 2004). Collectively, these results confirm that mining-related effects on macroinvertebrate communities continue to occur in the upper Black River and upper Meramec River watersheds, including segments of the West Fork of the Black River, Bee Fork, Strother Creek, and to a lesser degree Sweetwater Creek, Courtois Creek, and Logan Creek.

Food-web interactions and other secondary effects may also be associated with detrimental effects at sites below mining. In addition to metals, sedimentation and increased algae blooms were identified as likely causes for declines in benthic macroinvertebrate diversity and taxa richness following episodic releases of tailings or discharges from settling ponds in Bee Fork and Strother Creek during the period 1965-1971 (Gale et al. 1973; Ryck 1974). Sedimentation was visually apparent for up to 8 months at several sites within the same stream reaches included in our study, even though no exceedances in water quality criteria for heavy metals were detected at that time (Duchrow 1983). These effects have also been identified at stream sites in the Old Lead Belt (Lister and Humphrey 2005). In our study, higher estimates of substrate embeddedness and percentages of finer substrate size classes were observed at some mining sites as compared to reference sites, which may partially account for lower benthic diversity (Tables 3 and 4). This is further supported by the significant difference in these two parameters between $\mathrm{R}$ and $\mathrm{M}$ sites in 
the 2004 sampling (Table 5). Similar effects have been reported in other studies (Hoiland and Rabe 1992).

Even though we did not measure algal biomass, the accumulation of heavy metals by periphyton in riffle areas has been known to have a negative effect on macroinvertebrates in the scraper and collector functional groups (Axtmann and Luoma 1991; Dixit and Whitcomb 1983; Timmermans et al. 1989; Smock 1983; Scheiring 1993). In our study, there were elevated metal concentrations in invertebrates and plants at many of the mining sites (Besser et al. 2007), and snail taxa in the scraper functional group were absent at the upper Strother Creek site (J. Besser, unpublished data). Crayfish (collector functional group) were also absent from this site, and other sites directly below mining such as WF3 had among the lowest crayfish densities (Allert et al. 2008). Collectively, this information indicates that abundances of macroinvertebrates in the scraper and collector functional groups are the most severely affected by mining activities, probably because they ingest periphyton and particulate organic matter associated with stream substrates in riffle areas, which is typically enriched with metals (Besser et al. 2007). Most mining sites examined in this study had scraper abundances that were considerably lower than that found at reference sites. The value of including this functional group when calculating macroinvertebrate assessment metrics as part of evaluations in metal-contaminated streams has been recognized in other studies (Poulton et al. 1995; Carlisle and Clements 1999). Scraper abundance is also one of the metrics recommended as part of the development of multimetric indices in bioassessment studies (Kerans and Karr 1994; Barbour et al. 1999; Poulton et al. 2007).

Sites in the D category were expected to represent recovery zones located far enough below mines and tailings where ecological impacts might potentially be reduced from precipitation of metals and/or dilution from tributaries. In general, pore water concentrations of all metals declined with distance downstream of mining (Besser et al. 2009). This result is consistent with previous studies that have documented amelioration of metals concentrations with longitudinal distance downstream of mining activities (Gale et al. 1973;
Hudson-Edwards et al. 1997). Although sites in the $\mathrm{D}$ category did not have biological condition scores that differed significantly from reference sites (Table 5), they were generally lower than reference site scores (Fig. 3). For example, the lower Strother Creek site (SC3) is located below the confluence with Neals Creek, a tributary stream that was reported as contaminated by mining activities in previous studies (Wixson 1977). However, Besser et al. (2007) reported an overall decline in the concentrations of metals in biota collected from this stream since the 1970s. Dilution from this tributary may be the reason why macroinvertebrate scores at SC3 were not significantly lower than scores at reference sites even though this Strother Creek site is only $3 \mathrm{~km}$ downstream of SC2.

In comparing $\mathrm{SC} 2$ with $\mathrm{SC} 3$, the lower site (SC3) had a more diverse and evenly distributed dominance of EPT taxa, whereas the upper site (SC2) contained the tolerant mayfly Tricorythodes sp. as the dominant EPT taxa, and stoneflies were absent. Some studies have indicated that mayflies with higher tolerances to heavy metals can increase in dominance in metal-contaminated streams (Sumi et al. 1991). In our study, impacts on benthic macroinvertebrates could not be readily detected at SC3, even though elevated concentrations of metals were present in fish (Schmitt et al. 2007a, b) and invertebrates (Besser et al. 2007) at some of the D sites. This result was also observed at several other sites in this category (WF2, WF4, BF6). Similarly, we observed no impacts on macroinvertebrates at site MF3 during one of the two sampling periods (2003), possibly because two second-order tributaries with no mining in their watersheds enter the Middle Fork of the Black River above this site, providing potential for dilution and amelioration of metals effects. One of these tributaries, Brushy Creek, was examined as a nonmining control in previous studies (Ryck 1974). These results indicate that dilution of metals due to tributaries that have no mining impacts may be important for maintaining aquatic life in some reaches, but not significant enough to eliminate all risks to aquatic organisms found in these watersheds.

Brumbaugh et al. (2007) compared concentrations of $\mathrm{Pb}$ and $\mathrm{Zn}$ in surface water samples 
collected in 1995 (Femmer 2004) from the West Fork site directly below the mine and tailings (WF3) with those collected in 2003 and concluded that concentrations were declining at this site. This decline was attributed to the termination of milling operations at the West Fork mine in 2000. In our study, site WF3 did cluster with the other mining sites (Fig. 5a, b) and had relatively low total taxa richness, EPT richness, diversity index values, and scraper abundances as compared to the upstream reference site on the West Fork (WF1). Similarly, the decline in metals concentrations in aquatic biota at Neals Creek reported previously (Wixson 1977; Besser et al. 2007) is attributed to the termination of milling activities at the Magmont mine in 1994. Concentrations of metals in biota have generally declined over time at some of the same stream reaches where previous milling operations have since ended (Wixson 1977; Besser et al. 2007; Brumbaugh et al. 2007). The degree to which negative impacts can no longer be detected is probably related to the recovery period needed to flush metals from stream sediments after mines have been closed. Previous studies have indicated that recovery of aquatic life may take many years after milling or smelting operations have ended (Chadwick et al. 1986; Hoiland et al. 1994). This recovery period probably varies depending on the type and quantity of mine tailings in the watershed, the extent of the contamination, the length of time that mines were in operation, and geochemical and hydrologic factors.

The biological assessment approach used in this study was based on the framework developed by the state of Missouri for determining aquatic life support status (Sarver et al. 2002) to fulfill requirements of the Clean Water Act. We selected the sampling method, assessment protocol, and site scoring framework that was consistent with that used for evaluating the quality of Missouri streams (MDNR 2003) so that stream sites could be assigned to specific well-defined impairment categories. Even though the MDNR typically reports impairment status of streams based on samples that integrate multiple habitats, the proposed criteria values for coarse substrate in riffle areas allowed us to standardize our assessment across all sites. Further, this habitat was used for data collection as part of other study components, which allowed our study to more effectively compare macroinvertebrate indicators with metals concentrations in water, biota, and sediment pore water. The category boundaries associated with the four core response metrics used to derive the SCI (Table 2) have been determined as part of the development of numerical biological criteria for aquatic life protection. Even though numerical biocriteria have been implemented as aquatic life standards in other states (Yoder and DeShon 2003), these values have yet to be incorporated into water quality compliance requirements for Missouri (R. Sarver, personal communication). As recommended by Karr and Kerans (1991) and Barbour et al. (1995), we selected additional response metrics and calculated a separate multimetric score for the study sites to provide a more comprehensive and robust assessment and to facilitate comparisons between relative biotic condition and other indicators examined in the overall study.

Concentrations of most metals in sediment and biota determined during the overall USGS study are considerably lower than in historical lead-zinc mining areas of Missouri, such as those in the Old Lead Belt (Schmitt and Finger 1982; Besser et al. 2007; Brumbaugh et al. 2007). However, elevated concentrations of $\mathrm{Zn}$ and $\mathrm{Pb}$ in stream sediments at many of the same locations below mining activities were identified during the 1990 s as potentially harmful to aquatic organisms (Petersen et al. 1998). Macroinvertebrate species that tolerate heavy metals at contaminated sites also may increase the risk of metals to higher trophic levels. Crayfish and other aquatic macroinvertebrates, which were found to accumulate elevated concentrations of metals at our mining sites (Besser et al. 2007), are important food items for stream fishes in the Ozark region (Probst et al. 1984; DiStefano 2005; Pflieger 1996; Rabeni 1992), including popular sport fish such as the smallmouth bass (Micropterus dolomieu). Food web transfer of metals has been identified as a critical link in the determination of injury to natural resources from mining activities (Woodward et al. 1994, 1995).

We also included sites located in the EA (Fig. 1) because mining may occur there in the future. The Greer Spring site (GRS), in contrast with mining-contaminated sites, exceeded 
expectations for the EPT metric in our study and had the highest total and EPT taxa richness among all sites included in our assessment. This site is located on the spring branch directly downstream of the spring origin, where the annual water temperature variation is minimal (Vinyard and Feder 1974). Due to its resident cold water fauna, we applied different metric ranges for macroinvertebrate scoring based on the recommendations made in the state bioassessment protocol for the Current/Black River EDU (Sarver et al. 2002; MDNR 2003; Sowa et al. 2007). However, the difference in cold water and warm water site scoring criteria did not influence the placement of this site, which was assigned an aquatic life status of fully supporting. Much of the recharge areas identified for large springs in Missouri such as Greer Spring (GRS) and nearby Big Spring (Vinyard and Feder 1974; Imes et al. 2007) are located within the EA (Fig. 1). The Greer Spring branch contains potentially sensitive aquatic macroinvertebrate species such as the coldwater crayfish (Orconectes eupunctus) and the caddisflies (Tricoptera) Ceratopsyche piatrix (Hydropsychidae), Ochrotrichia contortra (Hydroptilidae), and Agepetus artesus (Glossosomatidae), all of which are listed as Species of Conservation Concern by the state of Missouri due to their rarity and limited geographic distributions (Missouri Natural Heritage Program 2007). These species are cold water ecological equivalents to some of the warm water taxa that have been known to accumulate metals at our mining sites (Besser et al. 2007) or were only present in macroinvertebrate samples taken at our other reference sites (WF1, BC, SK). Thus, future mining in the recharge areas of these springs may be potentially harmful to these species.

Yoder and DeShon (2003) highlighted the need for multi-indicator research studies that include both exposure indicators (i.e., tissue accumulation of metals in biota) and response indicators (toxicity tests and community-level assessments of biological condition) for effective environmental assessments in aquatic systems. Based on our relative biological condition scores, macroinvertebrate communities are negatively affected by mining activities at many of the sites where elevated concentrations of metals in sediment pore water and aquatic biota have been documented (Besser et al. 2007, 2009; Brumbaugh et al. 2007). Winner et al. (1980) suggested that macroinvertebrate communities should demonstrate a predictable graded response to varying concentrations of heavy metals in streams. The scoring and ranking of sites and the designation of site categories we outlined in this study $(\mathrm{A}, \mathrm{B}, \mathrm{C})$ represents a gradient in biotic conditions. Our macroinvertebrate results were well-correlated with environmental variables that are indicative of mining activities, including specific conductance, concentrations of metals in sediment pore water, toxic units, and some factors related to substrate quality (Table 5). Further, our individual response metrics and overall biological condition scores correlated well with results of laboratory toxicity studies conducted with sediments collected concurrently from the same sites (reported in Besser et al. 2009). This concurrence among exposure and response indicators supports the concepts outlined in the Biological Condition Gradient model, which depicts the relationship between a gradient of stressors or human disturbance and a graded biological response in the environment (Davies and Jackson 2006). Overall, this concurrence across indicators also provides a weight-of-evidence approach for identifying sites with adverse effects and demonstrates that macroinvertebrates and other aquatic organisms are useful for indicating the extent of these effects. Collectively, our results generally indicate that releases of heavy metals associated with mining activities were the underlying cause of reduced biotic condition and impairment of aquatic life in the streams we studied.

The results of our macroinvertebrate assessment indicate that some stream segments in the upper Black River and upper Meramec River watersheds are impaired and that riffle habitats within these stream segments do not fully meet aquatic life expectations as defined by reference sites. Our study indicates that biological assessment approaches that rely on an existing framework of reference sites and multimetric site scoring, such as the one implemented for evaluating the impairment status of Missouri streams (Sarver et al. 2002; MDNR 2003), can be successfully used for measuring aquatic macroinvertebrate response to mining activities in the Ozark 
region. Based on the expectations set forth for aquatic macroinvertebrate communities inhabiting streams draining the Viburnum Trend (Sarver et al. 2002), the mine wastewater treatment currently implemented by active mines has not prevented impairment of aquatic life in these streams. The exact heavy metal sources and localized points of entry into streams draining the Viburnum Trend have not been fully investigated, and it is possible that more effective treatment systems for disposal and discharge of mine wastes may need to be implemented in the future.

Previously published components of the overall USGS study have concluded that concentrations of most metals downstream of currently active mines remain elevated as compared to reference streams and have not changed substantially since the 1970s (Besser et al. 2007, 2009). It is possible that any future mining activities in the southeastern Missouri Ozark region may pose additional environmental risks to aquatic organisms, including within other watersheds that are not currently contaminated. This is especially important considering that the EA includes streams and rivers with high recreational use and ecological value and recharge areas for significant spring systems that represent an ecologically important feature of the Ozark region (Vinyard and Feder 1974; Imes et al. 2007). However, there is an indication that concentrations of $\mathrm{Pb}$ in water and food-web organisms (fish, invertebrates, plant biomass) have declined in some watersheds where mines have either been closed or where milling operations have ceased (Besser et al. 2007; Brumbaugh et al. 2007). This indicates that biological recovery of downstream reaches is possible over time if inputs of metals from mine wastes can be mitigated or eliminated.

Acknowledgements This study is part of a congressionally funded project involving all scientific disciplines within USGS. The following agency individuals contributed assistance toward completion of this study: J. Arms, E. Brunson, K. Echols, R. Espejo, D. Hardesty, C. Ivey, R. Jacobson, L. Johnson, S. Koppi, J. Kunz, C. Lawler, T. May, S. Olson, L. Sappington, D. Stoppler, M. Struckhoff, C. Vishy, M. Walther, D. Whites, C. Witte, and R. Wright. M. Ellersieck of the University of Missouri assisted with statistical analysis. We also acknowledge the following individuals from the Missouri Department of Conservation (MDC) for their assistance: T. Boersig, M. Combes, R.
DiStefano, S. Geringer, S. Herleth-King, P. Horner, and J. Westhoff. We thank R. Sarver of MDNR, W. Mabee of $\mathrm{MDC}$, and two anonymous reviewers for their comments and suggestions provided during reviews of earlier manuscript versions. We greatly appreciate the help of the many private landowners who granted us permission to sample on their properties.

Disclaimer Any mention of trade names does not constitute government endorsement.

\section{References}

Allert, A. L., Fairchild, J. F., DiStefano, R. J., Schmitt, C. J., Besser, J. M., Brumbaugh, W. G., et al. (2008). Effects of lead-zinc mining on crayfish (Orconectes hylas) in the Black River watershed, Missouri, USA. Freshwater Crayfish, 16, 99-113.

Applegate, J. M., Baumann, P. C., Emery, E. B., \& Wooten, M. S. (2007). First steps in developing a multimetric macroinvertebrate index for the Ohio River. River Research and Applications, 23(7), 683697. doi:10.1002/rra.1011.

Axtmann, E. V., \& Luoma, S. N. (1991). Large-scale distribution of metal contamination in the fine grained sediments of the Clark Fork River, Montana. Applied Geochemistry, 6, 75-88. doi:10.1016/08832927(91)90064-V.

Bain, M. B., \& Stevenson, N. J. (1999). Aquatic habitat assessment: Common methods (p. 216). Bethesda, MD: American Fisheries Society.

Ball, J. (1982). Stream classification guidelines for Wisconsin. Madison, WI: Wisconsin Department of Natural Resources Technical Bulletin.

Barbour, M. T., Gerritsen, J., Snyder, B. D., \& Stribling, J. B. (1999). Rapid bioassessment protocols for use in streams and wadable rivers: Periphyton, benthic macroinvertebrates, and fish (2nd edn.). EPA 841/B99/002. Washington, DC: U.S. Environmental Protection Agency.

Barbour, M. T., Stribling, J. B., \& Karr, J. R. (1995). Multimetric approach for establishing biocriteria and measuring biological condition. In W. S. Davis \& T. P. Simon (Eds.), Biological assessment and criteria: Tools for water resource planning and decision making (pp. 63-77). Boca Raton: Lewis.

Besser, J. M., Brumbaugh, W. G., Allert, A. L., Poulton, B. C., Schmitt, C. J., \& Ingersoll, C. G. (2009). Ecological impacts of lead mining on Ozark streams: Toxicity of sediment and pore water. Ecotoxicology and Environmental Safety, 72, 516-526. doi:10.1016/ j.ecoenv.2008.05.013.

Besser, J. M., Brumbaugh, W. G., May, T. W., \& Schmitt, C. J. (2007). Biomonitoring of lead, zinc, and cadmium in streams draining lead-mining and non-mining areas, southeast Missouri, USA. Environmental Monitoring and Assessment, 129, 227-241. doi:10.1007/ s10661-006-9356-9. 
Brumbaugh, W. G., Petty, J. D., Huckins, J. N., \& Manahan, S. E. (2002). Stabilized liquid membrane device (SLMD) for the passive, integrative sampling of labile metals in water. Water, Air, and Soil Pollution, 133, 109-119. doi:10.1023/A:1012923529742.

Brumbaugh, W. G., May, T. W., Besser, J. M., Allert, A. L., \& Schmitt, C. J. (2007). Assessment of elemental concentrations in streams of the New Lead Belt in southeastern Missouri, 2002-05. United States Geological Survey Scientific Investigations Report SIR 2007-5057. http://pubs.usgs.gov/sir/2007/5057/pdf/ SIR07-5057.pdf. Accessed 24 October 2008.

Burrows, I. G., \& Whitton, B. A. (1983). Heavy metals in water, sediments and invertebrates from a metalcontaminated river free of organic pollution. Hydrobiologia, 106, 263-273. doi:10.1007/BF00008125.

Cain, D. J., Luoma, S. N., Carter, J. L., \& Fend, S. V. (1992). Aquatic insects as bioindicators of trace element contamination in cobble-bottom rivers and streams. Fisheries and Aquatic Sciences, 49, 2141-2154.

Carlisle, D. M., \& Clements, W. H. (1999). Sensitivity and variability of metrics used in biological assessments of running waters. Environmental Toxicology and Chemistry, 18(2), 285-291. doi:10.1897/ 1551-5028(1999)018<0285:SAVOMU > 2.3.CO;2.

Chadwick, J. W., Canton, S. P., \& Dent, R. L. (1986). Recovery of benthic invertebrate communities in Silver Bow Creek, Montana, following improved metal mine wastewater treatment. Water, Air, and Soil Pollution, 28, 427-438.

Clements, W. H., Carlisle, D. M., Lazorchak, J. M., \& Johnson, P. C. (2000). Heavy metals structure benthic communities in Colorado mountain streams. Ecological Applications, 10, 626-638. doi:10.1890/ 1051-0761(2000)010[0626:HMSBCI]2.0.CO;2.

Cuffney, T. F., Gurtz, M. E., \& Meador, M. R. (1993). Methods for collecting benthic invertebrate samples as part of the National Water-Quality Assessment Program. United States Geological Survey Open File Report 93-406. http://water.usgs.gov/nawqa/protocols/ OFR-93-406/. Accessed 24 October 2008.

Czarneski, J. (1985). Accumulation of lead in fish from Missouri streams affected by lead mining. Bulletin of Environmental Contamination and Toxicology, 34, 736-745. doi:10.1007/BF01609801.

Davies, S. P., \& Jackson, S. K. (2006). The Biological Condition Gradient-A conceptual model for interpreting detrimental change in aquatic ecosystems. Ecological Applications, 16(4), 1251-1266. doi:10. 1890/1051-0761(2006)016[1251:TBCGAD]2.0.CO;2.

DiStefano, R. J. (2005). Trophic interactions between Missouri Ozarks stream crayfish communities and sport fish predators: Increased abundance and size structure of predators cause little change in crayfish community densities. Final report, Dingell-Johnson Project F-1-R-054, Study S-41, Job 4, Missouri Department of Conservation, Columbia, MO.

Dixit, S. S., \& Whitcomb, D. (1983). Heavy metal burden in water, substrate, and macroinvertebrate body tissue of a polluted River Irwell (England). Environmental Pollution (Series B), 6, 161-172.
Duchrow, R. M. (1983). Effects of lead tailings on benthos and water quality of three Ozark streams. Transactions of the Missouri Academy of Science, Missouri Academy of Science, 17(2), 5-17.

Duchrow, R. M., Robinson-Wilson, E., \& Trial, L. (1980). The effects of lead mine tailings on the water quality of Logan Creek, Reynolds County, Missouri. Internal report 1980, p. 29. Columbia, MO: Missouri Department of Conservation.

Eisler, R. (1988). Lead hazards to fish, wildlife, and invertebrates: A synoptic review. Contaminant hazard reviews. Biological report 85 (1.14). Laurel, MD: U.S. Fish and Wildlife Service, Patuxent Wildlife Research Center.

Feldmann, R. S., \& Connor, E. F. (1992). The relationship between $\mathrm{pH}$ and community structure of invertebrates in streams of the Shennandoah $\mathrm{Na}$ tional Park, Virginia, U.S.A. Freshwater Biology, 27, 261-276. doi:10.1111/j.1365-2427.1992.tb00538.x.

Femmer, S. R. (2004). Background and comparison of water-quality, streambed-sediment, and biological characteristics of streams in the Viburnum Trend and the exploration study areas, southern Missouri. Waterresources investigations report 03-4285. Reston, VA: U.S. Geological Survey.

Ferderer, D. A. (1996). National Overview of Abandoned Mine Land Sites Utilizing the Minerals Availability System (MAS) and Geographic Information System (GIS) Technology. U.S. Geological Survey Open-File Report 96-549. http://pubs.usgs.gov/of/1996/ofr-960549/ofr-96-549.html. Accessed 24 October 2008.

Gale, N. L., Wixson, B. G., Hardie, M. G., \& Jennett, J. L. (1973). Aquatic organisms and heavy metals in Missouri's new lead belt. American Water Resources Bulletin, 9, 673-688. doi:10.1111/j.1752-1688.1973. tb01790.x.

Haggard, B. E., Storm, D. E., Tejral, R. D., Popova, Y. A., Keyworth, V. G., \& Stanley, E. H. (2001). Stream nutrient retention in three northeastern Oklahoma agriculture catchments. Transactions of the American Society of Agricultural and Biological Engineers, 44(3), 597-605.

Hamilton, K., \& Bergersen, E. P. (1984). Methods to estimate aquatic habitat variables. U.S. Fish and Wildlife Service (p. 372). Fort Collins: Cooperative Fishery Research Unit, Colorado State University.

Hayslip, G. A. (1993). EPA Region 10 in-stream biological monitoring handbook (for wadeable streams in the Pacific Northwest). Environmental Services Division, EPA-910-9-92-013. Seattle, WA: U.S. Environmental Protection Agency.

Hoiland, W. K., \& Rabe, F. W. (1992). Effects of increasing zinc levels and habitat degradation on macroinvertebrate communities in three northern Idaho streams. Journal of Freshwater Ecology, 7(4), 373-380.

Hoiland, W. K., Rabe, F. W., \& Biggam, R. C. (1994). Recovery of macroinvertebrate communities from metal pollution in the South Fork and mainstem of the Coer d'Alene River, Idaho. Water Environment Research, 66(1), 84-88. 
Hudson-Edwards, K., Macklin, M., \& Taylor, M. (1997). Historic metal mining inputs to Tees river sediment. The Science of the Total Environment, 194/195, 437-445. doi:10.1016/S0048-9697(96)05381-8.

Humphrey, S., \& Lister, K. (2004). Biological assessment study: Indian Creek and Courtois Creek, Washington County, 2001-2002. Jefferson City, MO: Department of Natural Resources.

Imes, J. L. (2002). Geohydrological and biological investigations associated with a new lead-zinc exploration area near Winona, Missouri, and the Viburnum Trend of southeastern Missouri. Fact Sheet FS 0005-02. Rolla, MO: U.S. Geological Survey.

Imes, J., Plummer, N. L., Kleeshculte, M. J., \& Schumacher, J. G. (2007). Recharge area, baseflow and quick-flow discharge rates and ages, and general water quality of Big Spring in Carter County, Missouri, 2000-04. Scientific investigations report 2007-5049. Rolla, MO: U.S. Geological Survey.

Jessey, D. R. (1981). An investigation of the nickelcobalt occurrence in the southeast Missouri mining district. Ph.D. dissertation, University of Missouri-Rolla, p. 217.

Karr, J. R., \& Kerans, B. L. (1991). Components of biological integrity: Their definition and use in development of an invertebrate IBI. Environmental sciences division report 905-R-92-003. Chicago, IL: U.S. Environmental Protection Agency.

Kerans, B. L., \& Karr, J. R. (1994). A benthic index of biotic integrity (B-IBI) for rivers of the Tennessee Valley. Ecological Applications, 4(4), 768785. doi:10.2307/1942007.

Kiffney, P. M., \& Clements, W. H. (1994). Effects of heavy metals on a macroinvertebrate assemblage from a Rocky Mountain stream in experimental microcosms. Journal of the North American Benthological Society, 13(4), 511-523. doi:10.2307/1467847.

Kleeschulte, M. J. (2000). Ground- and surface-water relations in the Eleven Point and Current River Basins, south-central Missouri. Fact Sheet 032-00. Rolla, MO: U.S. Geological Survey.

Kleeschulte, M. J. (2003). Geohydrological and biological investigations associated with lead-zinc exploration and mining in southeastern Missouri. http://mo. water.usgs.gov/mining/leadmining.htm.

Kleeschulte, M. J., \& Seeger, C. M. (2003). Stratigraphy and vertical hydraulic specific conductance of the St. Francois confining unit in the Viburnum Trend and evaluation of the unit in the Viburnum Trend and exploration areas, southeastern Missouri. WaterResources Investigations Report 03-4329. Rolla, MO: U.S. Geological Survey Report.

Klemm, D. J., Lewis, P. A., Fulk, F., \& Lazorchak, J. M. (1990). Macroinvertebrate field and laboratory methods for evaluating the biological integrity of surface waters. EPA/600/4-90/030. Location: U.S. Environmental Protection Agency, Office of Research and Development, Environmental Monitoring Series Report.

Kreis, R. G. Jr. (1988). Integrated study of exposure and biological effects of in-place sediment pollutant in the upper connecting channels [Trenton Channel, Detroit
River]: Interim results. Grosse Ile, MI: U.S. Environmental Protection Agency, LLRS.

Lister, K. B., \& Humphrey, S. (2005). Biological assessment and fine sediment study: Big River (lower): Irondale to Washington State Park, St Francois, Washington, and Jefferson Counties, Missouri. Jefferson City, MO: Missouri Department of Natural Resources.

Mining and Quarry World (2004). U.S. lead leader. Mining and Quarry World Journal, 1(3), 14-21.

Missouri Department of Natural Resources (MDNR) (2003). Semi-quantitative macroinvertebrate stream bioassessment project procedure. Jefferson City, MO: Air \& Land Protection Div., Environmental Services Program.

Missouri Department of Natural Resources (MDNR) (2004). The mineral industry of Missouri: Geological Survey and Resources Assessment Division. http://minerals.usgs.gov/minerals/pubs/state/2004/ mostmyb04.pdf.

Missouri Department of Natural Resources (MDNR) (2007). The stat0065 of Missouri's Environment: 2007. Pub. \#1332. Jefferson City, MO.

Missouri Natural Heritage Program. (2007). Missouri species and communities of conservation concern checklist. Jefferson City, MO: Missouri Dept. of Conservation.

Petersen, J. C., Adamski, J. C., Bell, R. W., Davis, J. V., Femmer, S. R., Freiwald, D. A., et al. (1998). Water quality in the Ozark Plateaus, Arkansas, Kansas, Missouri, and Oklahoma, 1992-95. Circular, 1158. Denver, CO: U.S. Geological Survey.

Pflieger, W. L. (1996). The crayfishes of Missouri. Jefferson City, MO: Missouri Department of Conservation.

Platts, W. S., Megahan, W. F., \& Minshall, G. W. (1983). Methods for evaluating stream, riparian, and biotic conditions. General technical report INT-138. Ogden, UT: U.S. Dept. of Agriculture, Intermountain Forest and Range Experiment Station.

Poulton, B. C., Monda, D. P., Woodward, D. F., Wildhaber, M. L., \& Brumbaugh, W. G. (1995). Relations between benthic community structure and metals concentrations in aquatic macroinvertebrates: Clark Fork River, Montana. Journal of Freshwater Ecology, 10(3), 277-293.

Poulton, B. C., Rasmussen, T. J., \& Lee, C. J. (2007). Assessment of biological conditions at selected stream sites in Johnson County, Kansas and Cass and Jackson Counties, Missouri, 2003 and 2004. Scientific Investigations Report 2007-5108. Columbia, MO: U.S. Geological Survey.

Probst, W. E., Rabeni, C. F., Covington, W. G., \& Marteney, R. E. (1984). Resource use by streamdwelling rock bass and smallmouth bass. Transactions of American Fisheries Society, 113, 283-294.

Rabeni, C. F. (1992). Trophic linkage between stream centrarchids and their crayfish prey. Canadian Journal of Fisheries and Aquatic Science, 49, 1714-1721.

Rabeni, C. F., \& Doisy, K. E. (2000). Correspondence of stream benthic invertebrate assemblages to regional classification schemes in Missouri. Journal of the North American Benthological Society, 19(3), 419-428. 
Rabeni, C. F., \& Sowa, S. P. (2002). A landscape approach to managing the biota of rivers and streams. In J. Liu and W. W. Taylor (Eds.), Integrating landscape ecology into natural resource management (pp. 114-142). Cambridge: Cambridge University Press.

Reish, D. J., \& Gerlinger, T. V. (1964). The effects of cadmium, lead, and zinc on survival and reproduction in the polychaetous annelid Neanthes arenaceodentata (F. Nereididae). In P. A. Hutchings (Ed.), Proceedings of the first international polychaete conference (pp. 383-389). Sidney: Linnean Society N.S.W.

Rosenberg, D. M., \& Resh, V. H. (Eds.) (1993). Freshwater biomonitoring and benthic macroinvertebrates (p. 488). New York: Chapman and Hall.

Ryck, F. M. (1974). Water quality survey of the southeast Ozark mining area, 1965-1971., Aquatic Series report no. 10. Jefferson City, MO: Missouri Department of Conservation.

Ryck, F. M., \& Whitley, J. R. (1974). Pollution abatement in the lead mining district of Missouri. Proceedings of the Purdue Industrial Waste Conference, 29, 857-863.

Sarver, R. J., \& McCord, S. (2005). Taxonomic levels for macroinvertebrate identifications, and biotic index values for macroinvertebrate taxa found in Missouri. SOP\# MDNR-WQMS-209. Jefferson City, MO: Missouri Department of Natural Resources, Air \& Land Protection Division, Environmental Services Program.

Sarver, R., Harlan, S., Rabeni, C. F., \& Sowa, S. P. (2002). Biological criteria for wadeable/perennial streams of Missouri. Jefferson City, MO: Missouri Department of Natural Resources, Air \& Land Protection Division, Environmental Services Program.

Scheiring, J. F. (1993). Effects of surface mine drainage on leaf litter insect communities and detritus processing in headwater streams. Journal of the Kansas Entomological Society, 66(1), 31-40.

Schmitt, C. J., \& Finger, S. E. (1982). The transport, fate, and effects of trace metals in the Big and Black River watersheds, Southeastern Missouri. Final report to U.S. Army Corps of Engineers, U.S. Fish and Wildlife Service, Columbia National Fisheries Research Laboratory, Columbia, MO.

Schmitt, C. J., \& Finger, S. E. (1987). The effects of sample preparation on the measured concentrations of eight elements in the edible tissues of fish contaminated by lead mining. Archives of Environmental Contamination and Toxicology, 16, 185-207.

Schmitt, C. J., Wildhaber, M. L., Hunn, J. B., Nash, T., Tieger, M. N., \& Steadman, B. L. (1993). Biomonitoring of lead-contaminated Missouri streams with an assay for erythrocyte $\delta$-aminolevulinic acid dehydratase (ALA-D) activity in fish blood. Archives of Environmental Contamination and Toxicology, 25, 464-475.

Schmitt, C. J., Brumbaugh, W. G., \& May, T. W. (2007a). Accumulation of metals in fish from lead-zinc mining areas of southeastern Missouri, USA. Ecotoxicology and Environmental Safety, 67(1), 14-30.

Schmitt, C. J., Whyte, J. J., Roberts, A. P., Annis, M. L., \& Tillitt, D. E. (2007b). Biomarkers of metals exposure in fish from lead-zinc mining in southeastern Missouri,
USA. Ecotoxicology and Environmental Safety, 67(1), 31-47.

Shackleford, B. (1988). Rapid bioassessments of lotic macroinvertebrate communities: Biocriteria development (p. 44). Little Rock: Arkansas Department of Pollution Control and Ecology.

Smock, L. A. (1983). The influence of feeding habits on whole-body metals concentrations in aquatic insects. Freshwater Biology, 13, 301-311.

Soucek, D. J., Cherry, D. S., Currie, R. L., Latimer, H. A., \& Claire, T. G. (2000). Laboratory to field validation in an integrative assessment of an acid mine drainageimpacted watershed. Environmental Toxicology and Chemistry, 19(4), 1036-1043.

Sowa, S. P., Annis, G. M., Diamond, D. D., Figg, D., Morey, M. E., \& Nigh, T. (2004). An overview of the data developed for the Missouri Aquatic GAP project and an example of how it is being used for conservation planning. Gap Analysis Bulletin, 12, 7-19.

Sowa, S. P., Annis, G. M., Morey, M. E., \& Diamond, D. D. (2007). A gap analysis and comprehensive conservation strategy for riverine ecosystems of Missouri. Ecological Monographs, 77(3), 301-334.

Starnes, L. B., \& Gasper, D. C. (1996). Effects of surface mining on aquatic resources in North America. Fisheries, 21(5), 24-26.

Sumi, Y., Fukuoka, H. R., Murakami, T., Suzuki, T., Hatakeyama, S., \& Suzuki, K. T. (1991). Histochemical localization of copper, iron and zinc in the larvae of the mayfly Baetis thermicus inhabiting a river polluted with heavy metals. Zoological Science, 8, 287-293.

Timmermans, K. R., Van Hattum, B., Kraak, M. H. S., \& Davids, C. (1989). Trace metals in a littoral foodweb: Concentrations in organisms, sediment, and water. Science of the Total Environment, 87/88, 477-494.

U.S. Department of Agriculture (2005). Project plan for Mark Twain National Forest. http://www.fs.fed.us/r9/ forests/marktwain/projects/forest_plan/.

U.S. Environmental Protection Agency (1983). Waterbody surveys and assessments for conducting use attainability analysis. Technical support manual. Washington, DC: Office of Water Regulations and Standards.

U.S. Environmental Protection Agency (1990). Biological Criteria: National program guidance for surface waters. EPA-440/5-90-004. Washington, DC: Office of Water.

U.S. Environmental Protection Agency (1994). Lead-zinc mining industry profile, environmental effects. Technical resource document, extraction and beneficiation of ores and minerals, vol. I, lead-zinc. Washington, DC: Office of Solid Waste and Emergency Response.

U.S. Environmental Protection Agency (2000). National water quality inventory: 1998 report to Congress. EPA 841-R-00-001. Washington, DC.

U.S. Environmental Protection Agency (2002). National recommended water quality criteria. http://www.epa. gov/waterscience/criteria/aqlife.htm.

Vinyard, J. D., \& Feder, G. L. (1974). Springs of Missouri. Water resources report 29 (p. 212). Rolla, MO: Missouri Geological Survey and Water Resources. 
Washington, H. G. (1984). Diversity, biotic and similarity indices: A review with special reference to aquatic systems. Water Resources, 18(6), 653-694.

Wildhaber, M. L., \& Schmitt, C. J. (1996). Estimating aquatic toxicity as determined through laboratory tests of Great Lakes sediments containing complex mixtures of environmental contaminants. Environmental Monitoring and Assessment, 41, 255-289.

Winner, R. W., Boesel, M. W., \& Farrell, M. P. (1980). Insect community structure as an index of heavy metal pollution in lotic ecosystems. Canadian Journal of Fisheries and Aquatic Sciences, 37, 647-655.

Wixson, B. G. (Ed.) (1977). The Missouri lead study, vol. 1-An interdisciplinary investigation of environmental pollution by lead and other heavy metals from industrial development in the New Lead Belt of southeastern Missouri. Final report to National Science Foundation, Research Applied to National Needs Program, University of Missouri, Columbia and Rolla, Missouri.
Woodward, D. F., Brumbaugh, W. G., DeLonay, A. J., Little, E. E., \& Smith, C. E. (1994). Effects on rainbow trout fry of a metals-contaminated diet of benthic invertebrates from the Clark Fork River, Montana. Transactions of the American Fisheries Society, 123, 51-62.

Woodward, D. F., Farag, A. M., Bergman, H. L., DeLonay, E. E., Smith, C. E., \& Barrows, F. T. (1995). Metalscontaminated benthic invertebrates in the Clark Fork River, Montana: Effects on age-0 brown trout. Canadian Journal of Fisheries and Aquatic Sciences, 52, 1992-1994.

Yoder, C. O., \& DeShon, J. E. (2003). Using biological response signatures within a framework of multiple indicators to assess and diagnose causes and sources of impairments to aquatic assemblages in selected Ohio rivers and streams. In T. P. Simon (Ed.), Biological response signatures: Indicator patterns using aquatic communities (pp. 23-81). Boca Raton: Lewis. 